\title{
FUNDAMENTAL BASIS OF COVID-19 PATHOGENESIS
}

Sergey Brankovich Bolevich ${ }^{1}$, Peter Frantzevich Litvitsky², Sergei Vitalievich Grachev ${ }^{1}$, Sergey Ivanovich Vorobyev ${ }^{1}$ Alexandra Sergeevna Orlova ${ }^{1}$, Marina Anatolievna Fokina ${ }^{1}$, Alexei Alekseevich Novikov ${ }^{1}$, Stephani Sergeevna Bolevich ${ }^{2}$, Anastasia Yurievna Mikhaleva ${ }^{1}$, Elena Mihailovna Morozova ${ }^{1}$, Maria Konstantinovna Kartashova ${ }^{1}$, Koka Hasbulatovna Yavlieva ${ }^{1}$, Denis Vitalievich Gudanovich ${ }^{3}$, Ivan Srejovic ${ }^{4}$ and Vladimir Jakovljevic ${ }^{1,4}$

${ }^{1}$ Department of Human Pathology of the Institute of Clinical Medicine of Federal State Autonomous Educational Institution of Higher Education I.M. Sechenov First Moscow State Medical University of the Ministry of Health of the Russian Federation (Sechenov University), Moscow, Russia ${ }^{2}$ Department of Pathophysiology of the Institute of Clinical Medicine of Federal State Autonomous Educational Institution of Higher Education I.M. Sechenov First Moscow State Medical University of the Ministry of Health of the Russian Federation (Sechenov University), Moscow, Russia ${ }^{3}$ Research Institute of SP N.V. Sklifosovsky, Moscow, Russia

${ }^{4}$ University of Kragujevac, Faculty of Medical Sciences, Department of Physiology, Kragujevac, Serbia

\section{NAJZNAČAJNIJE OSNOVE PATOGENEZE COVID-19}

Sergey Brankovich Bolevich ${ }^{1}$, Peter Frantzevich Litvitsky², Sergei Vitalievich Grachev ${ }^{1}$, Sergey Ivanovich Vorobyev ${ }^{1}$,

Alexandra Sergeevna Orlova ${ }^{1}$, Marina Anatolievna Fokina ${ }^{1}$, Alexei Alekseevich Novikov ${ }^{1}$, Stephani Sergeevna Bolevich ${ }^{2}$, Anastasia Yurievna Mikhaleva ${ }^{1}$, Elena Mihailovna Morozova ${ }^{1}$, Maria Konstantinovna Kartashova ${ }^{1}, K^{1}$ oka Hasbulatovna Yavlieva ${ }^{1}$, Denis Vitalievich Gudanovich ${ }^{3}$, Ivan Srejovićc i Vladimir Jakovljević ${ }^{1,4}$

${ }^{1}$ Katedra za humanu patologiju Instituta za kliničku medicinu Savezne autonomne obrazovne ustanove visokog obrazovanja I. M. Sechenov Prvi moskovski državni medicinski univerzitet Ministarstva zdravlja Ruske Federacije (Sechenov univerzitet), Moskva, Rusija

${ }^{2}$ Katedra za patofiziologiju Instituta za kliničku medicinu Savezne autonomne obrazovne ustanove visokog obrazovanja I.M. Sechenov Prvi moskovski državni medicinski univerzitet Ministarstva zdravlja Ruske Federacije

${ }^{3}$ Istraživački institut SP N.V. Sklifosovski, Moskva, Rusija

${ }^{4}$ Univerzitet u Kragujevcu, Fakultet medicinskih nauka, Katedra za fiziologiju, Kragujevac, Srbija

\section{ABSTRACT}

At the end of 2019, a new coronavirus infection occurred in the People's Republic of China with an epicentre in the city of Wuhan. On February 11th, 2020, the World Health Organization assigned the official name of the infection caused by the new coronavirus - COVID-19. COVID-19 has affected people from all over the world given that the infection was noted in 200 countries resulting in annunciation of the pandemic situation. Human corona viruses cause mild to moderate respiratory infections. At the end of 2002, a new coronavirus appeared (SARS-CoV), the causal agent of atypical pneumonia, which caused acute respiratory distress syndrome (ARDS). The initial stage of COVID-19 infection is the penetration of SARS-CoV-2 into target cells that have angiotensin converting enzyme type II receptors. The virus enters the body through the respiratory tract and interacts primarily with toll-like receptors (TLRS). The events in SARS-Cov-2 induced infection follow the next scenario: epithelial cells via TLRs recognize and identify SARS-Cov-2, and after that the information is transmitted to the transcriptional $N F-\kappa B$, which causes expression of the corresponding genes. Activated in this way, the epithelial cells begin to synthesize various biologically active molecules. The results obtained on preclinical material indicate that ROS generation increases and the antioxidant protection decreases, which plays a major role in the pathogenesis of SARS-CoV, as well as in the progression and severity of this respiratory disease.

Keywords: World Health Organization, coronavirus COVID-19, respiratory infection, respiratory distress syndrome

\section{SAŽETAK}

Krajem 2019. godine, infekcija novim korona virusom se dogodila u Narodnoj Republici Kini sa središtem u gradu Vuanu. Jedanaestog februara, 2020. godine, Svetska Zdravstvena Organizacija je dala zvanično ime infekciji prourokovanoj novim korona virusom - COVID-19. Od COVIDA-19 su oboleli ljudi širom sveta uzimajući u obzir činjenicu da je infekcija zabeležena u 200 država što je imalo za posledicu objavu pandemije. Korona virusi od kojih oboljevaju ljudi prouzrokuju blage do umerene respiratorne infekcije. Krajem 2002. godine, pojavio se novi korona virus (SARS-CoV), uzročnik atipične pneumonije koja je prouzrokovala akutni respiratorni distres sindrom (ARDS). COVID-19 infekcija počinje prodiranjem SARS-CoV-2 u ciljne ćelije koje imaju receptore angiotenzin konvertujućeg enzima 2. Virus ulazi u telo kroz respiratorni trakt $i$ intereaguje prvenstveno sa Toll sličnim receptorima. Redosled dešavanja kod infekcije izazvane virusom SARSCov-2 je sledeći: epitelne ćelije preko TLR (eng. Toll Like Receptors) sličnih receptora prepoznaju i identifikuju SARS-Cov-2, i posle toga se informacija prenosi do transkripcionog NF-kB koji prouzrokuje ekspresiju odgovarajućih gena. Aktivirane na ovaj način, epitelne ćelije počinju da sintetišu različite biološki aktivne molekule. Rezultati dobijeni na prekliničkom materijalu nagoveštavaju da se stvaranje ROS povećava a antioksidativna zaštita smanjuje što igra glavnu ulogu u patogenezi SARS-CoV, kao i u progresiji i težini ove respiratorne bolesti.

Ključne reči: Svetska zdravstvena organizacija, koronavirus - KOVID-19, respiratorna infekcija, respiratorni distres sindrom

\section{sciendo}

UDK: 616.98:578.834

616.98-092

Ser J Exp Clin Res 2020; 21 (2): 93-111

DOI: $10.2478 /$ sjecr-2020-0029 


\section{CLASSIFICATION AND EPIDEMIOLOGICAL CHARACTERISTICS OF CORONAVIRUSES}

At the end of 2019, an outbreak of a new coronavirus infection occurred in the People's Republic of China (PRC) with an epicentre in the city of Wuhan (Hubei province), the causative agent of which was given the temporary name 2019-nCoV. On February $11^{\text {th }}, 2020$, the World Health Organization (WHO) assigned the official name of the infection caused by the new coronavirus - COVID-19 ("Coronavirus disease 2019"). The International Committee on virus taxonomy on February $11^{\text {th }}, 2020$, assigned the official name of the infectious agent-SARS-CoV-2 due to its high homology (approximately 80\%) with SARS-CoV, which caused acute respiratory distress syndrome (ARDS) and high mortality during 2002-2003 (1).

COVID-19 has affected people from all over the world given that the infection was noted in 200 countries resulting in annunciation of the pandemic situation by $\mathrm{WHO}(2,3)$.

It was believed that the first outbreak of SARS-CoV-2 occurred through the zoonosis transmission in the market of seafood in Wuhan, China. After some time, it was admitted that the transmission of virus among people played the main role (4).

Corona virus belongs to coronaviridae family - it is a large family of RNA-containing viruses, $30 \mathrm{~kb}$ in size, which are capable of infecting humans and some animals (5).

Currently it is known that there are four types of coronaviruses (HCoV-229E, -OC43, -NL63 и -HKU1) circulating in human population. Human corona viruses, such as $229 \mathrm{E}$ and NL63, cause mild to moderate respiratory infections. According to serological and phylogenetic analysis, coronaviruses are divided into four genera: Alphacoronavirus (Alpha-CoV), Betacoronavirus (Beta-CoV), Gammacoronavirus (Gamma-CoV) and Deltacoronavirus (Delta-CoV). Alpha$\mathrm{CoV}$ and Beta-CoV coronaviruses affect only mammals (6).

Before 2002, coronavirus was recognized as a cause of mild respiratory infections that have been fatal very rarely. At the end of 2002, a new coronavirus appeared (SARS$\mathrm{CoV}$ ), the causal agent of atypical pneumonia, which caused acute respiratory distress syndrome (ARDS). SARS-CoV belongs to the genus Beta-CoV. The natural reservoir of SARS$\mathrm{CoV}$ are bats, intermediate hosts are camels and Himalayan civets. In total, more than 8000 cases were registered in 37 countries around the world during the epidemic period, of which 774 were fatal. No new cases of SARS-CoV-induced ARDS have been reported since 2004. In 2012, the world encountered a new MERS coronavirus (MERS-CoV), a pathogen of the Middle East respiratory syndrome, which also belongs to the genus Beta-CoV. The main natural reservoir of MERS-CoV coronaviruses are single-humped camels. From 2012 to January $31^{\text {st }}, 2020,2519$ cases of coronavirus infection caused by the MERS-CoV virus were registered, of which 866 were fatal. All cases were geographically associated with the Arabian Peninsula (82\% of the cases are reported in Saudi Arabia). At the moment, MERS-CoV continues to circulate and causes new cases of the disease. The new SARS-CoV-2 coronavirus is classified as group II pathogenicity, as are some other members of this family (SARS$\mathrm{CoV}$ virus, MERS-CoV). SARS-CoV-2 coronavirus is believed to be a recombinant virus between a bat coronavirus and coronavirus of an unknown origin

\section{ROLES OF ACE2 AND TLR RECEPTORS IN SARS-COV-2 INFECTION}

The entrance gate of the pathogen is the epithelium of the upper respiratory tract and epithelial cells of the stomach and intestines. The initial stage of infection is the penetration of SARS-CoV-2 into target cells that have angiotensin converting enzyme type II (ACE2) receptors $(7,8)$.

ACE2 receptors exist in the population of endothelial cells in the respiratory tract, kidneys, oesophagus, bladder, ileum and central nervous system (CNS). ACE2 can be disposed by two proteases, ADAM17 and TMPRSS2. It was shown that the cleavage of ACE2 by TMPRSS2 can facilitate the penetration of SARS-CoV-2 into cells, while the action of ADAM17 on ACE2 may have a protective effect (9).

Virus (SARS-Cov2) $\rightarrow$ gets into the respiratory tract $\rightarrow$ interacts with Toll-like receptors of the bronchial epithelium $\rightarrow$ activates NF- $\kappa$ B (core factor of kappa B) $\rightarrow$ synthesis of interferons $\rightarrow$ activation of ACE2 (receptor of angiotensin converting enzyme) $\rightarrow$ penetration of SARSCov2 into the cell (bronchial epithelial cell) $\rightarrow$ replication of virus $\rightarrow$ damage of epithelial cell and its death

The virus enters the body through the respiratory tract and interacts primarily with Toll-like receptors (TLRs). TLRs are the main specialized cellular structures that are able to recognize various infectious agents, such as microbes, viruses, some protozoa (primarily their exotoxins and endotoxins) and initiate the expression of cytokines - biologically active substances that determine the formation and launch of mechanisms of non-specific resistance of the body. By recognizing the infectious aggression, TLRs immediately "sound the alarm", initiating the activation of anti-infectious protective and adaptive mechanisms of the body at the cellular level (Figure 1).

It is noteworthy that Toll-like receptors are expressed not only on phagocytes (monocytes, tissue macrophages and neutrophils) and immune-competent cells ( $\mathrm{T}$ and B lymphocytes), but also on many other types of cells - epithelial cells of the respiratory and urinary tracts, intestines, endothelial cells, keratocytes, microglial cells, that participate in the formation of anti-infective resistance of the body. 
Figure 1. Participation of Toll-like receptors in the formation of anti-infective non-specific resistance of the body

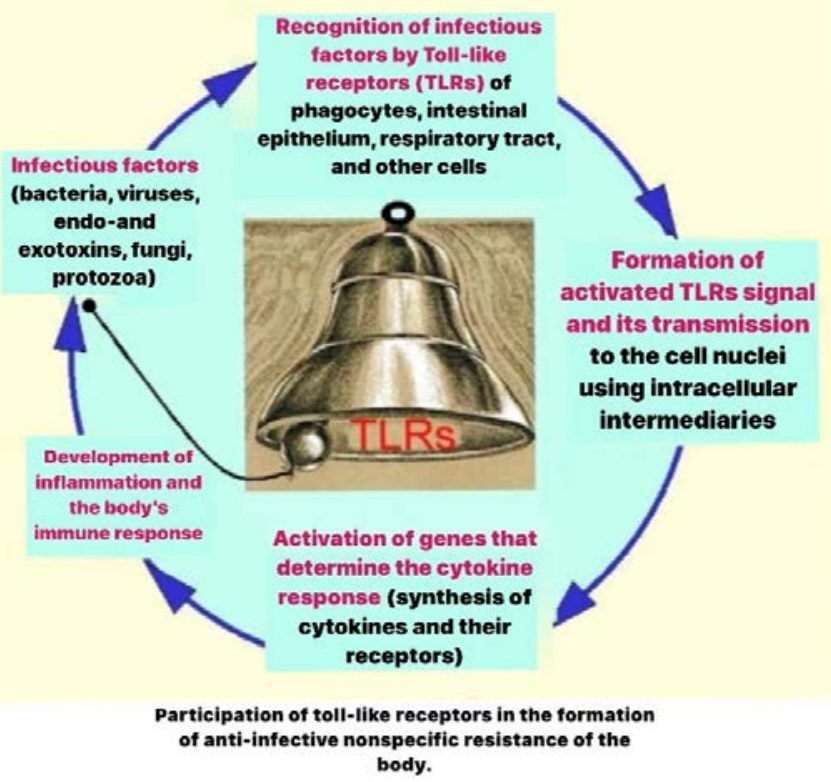

The figure was taken with the permission of the authors from Bolevich SB, Voinov VA. Molecular mechanisms in hu-man pathology. Medical Information Agency. 2012;208. (10)

13 types of TLRs have been identified in humans so far: from TLR-1 to TLR-13, but it is speculated that there are probably more. The majority of TLRs are transmembrane receptors: TLR-1,-2,-4,-5,-6,-10,-11 (Figure 2).

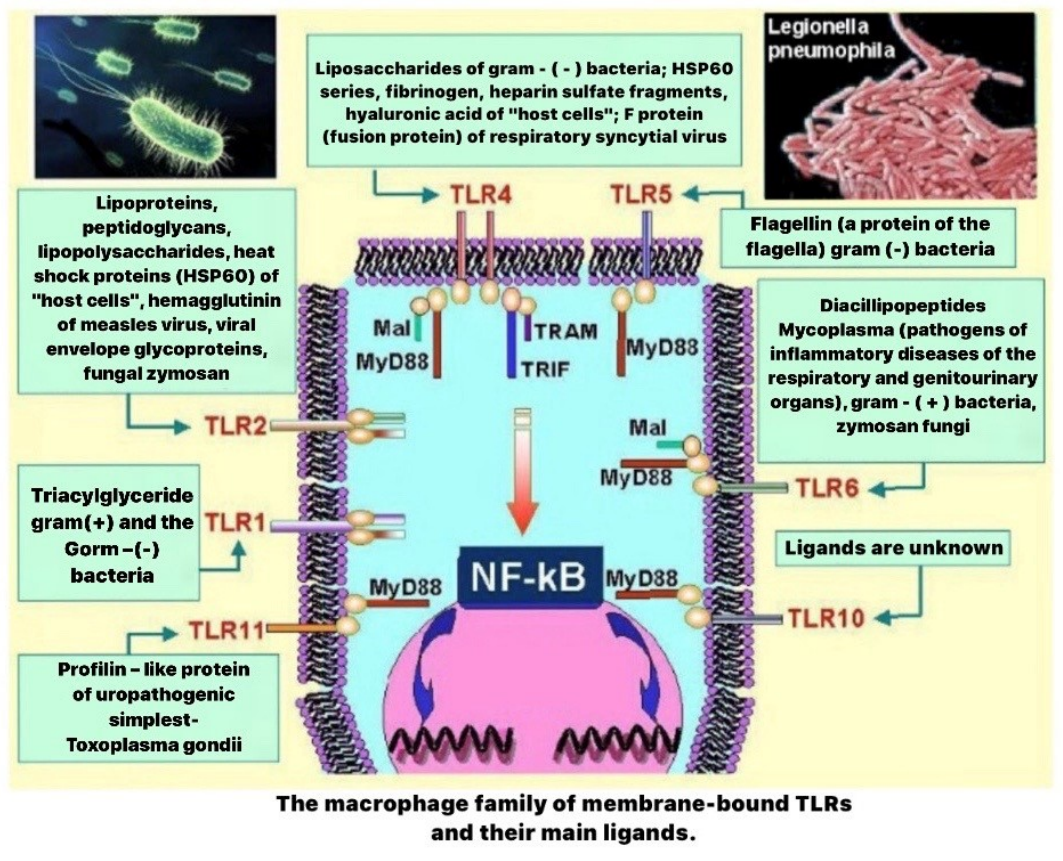

Figure 2. The macrophage membrane-bound TLRs family and their main ligands

The figure was taken with the permission of the authors from Bolevich SB, Voinov VA. Molecular mechanisms in hu-man pathology. Medical Information Agency. 2012;208. (10)

[Comment: Mal (or TIRAP), TRAM (or TICAM), TRIF (or TICAM-1), MyD88 these are intracellular adapter proteins that belong to the TIR domain group-containing proteins and participate in the transmission of signals from Toll-like receptors. Among them, MyD88-adapter-like (myeloid differentiated factor 88) is a universal adapter protein (almost all TLRs use MyD88 for their signal transduction) and, at the same time, - a specific protein for transmitting signals from TLR4 and TLR5. It is estab-

lished that TLR 5 mutations cause a predisposition to Legionnaire's disease (legionnaires), the cause of which is "Gramnegative flagellated bacteria" (pictured is an electronogram of Legionella pneumophila). Regarding the fact that flagellin is astrong adjuvant, it was found out that the mechanisms of its action at the cellular level can contribute to the creation of vaccinepreparations for the prevention of Legionnaire's disease.] 
Transmembrane receptors usually consist of 2 domains the extracellular, which provides direct interaction with ligands of microorganisms or their products, and the intracellular (cytoplasmic), which initiates translation of signals of activated TLR. After interacting with ligands, TLRs acquire the ability to bind intracellular adapter proteins that provide subsequent signal transmission.
Detection of viruses (SARS-Cov-2) and other intracellular microorganisms is the main goal of functioning of another family of TLRs, which are localized in the cytoplasm and on the internal structures of cells (Golgi apparatus). This small intracellular family combines TLR-3, TLR-7 and TLR-9 (Figure 3).

Figure 3. The family of intracellular TLRs and their main ligands

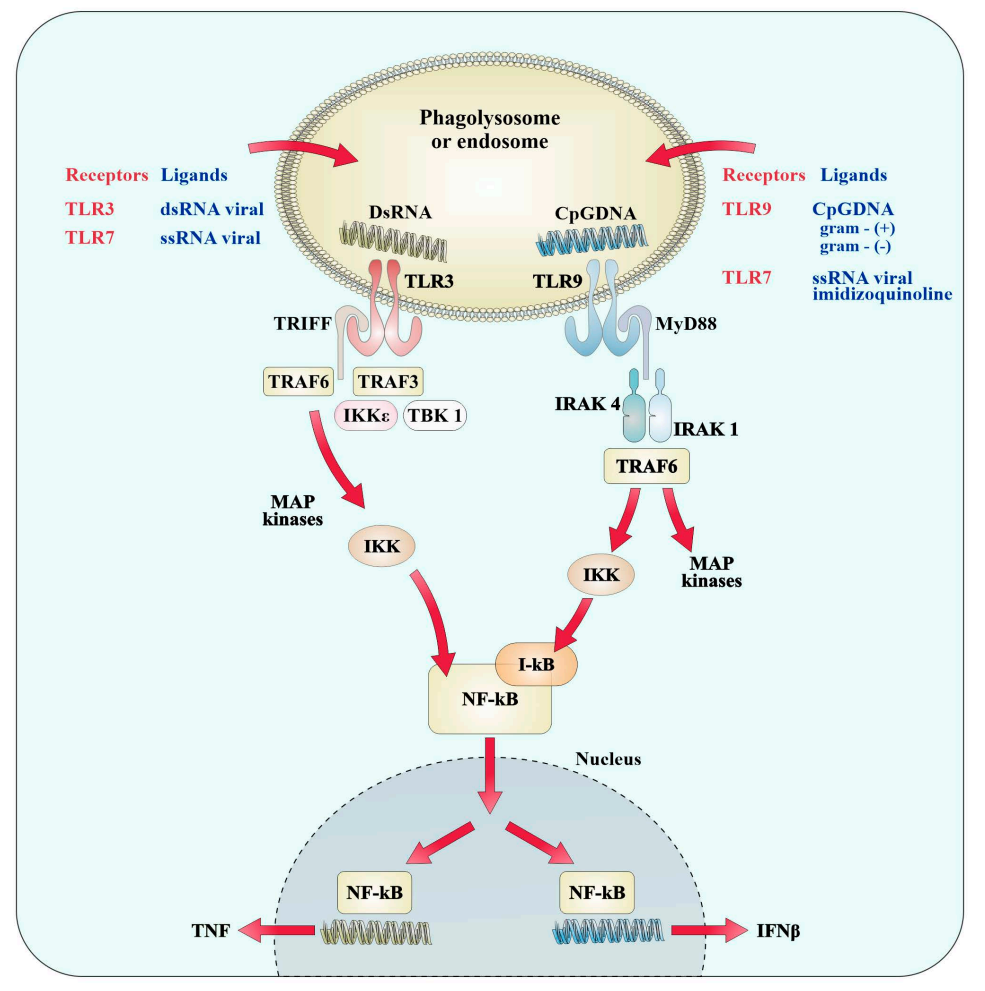

[Abbreviations: CpGDNA-cytosine phosphate guanosine containing the " motive " of DNA gram - (+) and gram - ( - ) bacteria; ssRNA viral-singlestranded RNA, dsRNA viral double - doublestranded RNA of viruses; IRAK1, IRAK4cytosolic enzymes of the group signal kinases; imidizoquinoline (imidizoquinoline) - synthetic antiviral drug; MyD88-myeloid differentiated factor 88; universal adapter protein; TRAF6-cytosolic adapter protein associated with the tumor necrosis factor receptor 6; TRAF3-cytosolic adaptive protein associated with the tumor necrosis factor receptor 3; MAP kinases-a cascade of enzymes that performs regulatory phosphorylation nuclear transcription factors; IKK is an inhibitor of the I-kB kinase complex (NF- $\kappa \mathrm{B}$ inhibitor); TRIF or TICAM-1-intracellular adapter protein, which belongs to the group of TIR domain-containing proteins and participates in signal transmission from toll-like receptors; TBK1-serotonin/threonine kinase involved in the cascade of signals that lead to the activation transcription of NF- $\mathrm{BB}$; TNFtumor necrosis factor, IFN - interferon]
Currently there are two variants of the molecular mechanisms for transmitting signals from activated TLRs: 1) MyD88-dependent and 2) MyD88-independent. The second pathway involves other (non-MyD88) adapter molecules, their combinations with each other or with MyD88. In particular, MyD88-dependent signal translation leads, for example, to the activation of NF- $\kappa \mathrm{B}$ and MARK kinase (Figure 4).

A landmark event in the studying of innate immunity was a detection of TLRs on endothelial cells and epithelial cells of the skin and mucous membranes. The traditional idea of the epithelial cover of the body as a passive mechanical barrier to infection has been enriched by a fundamentally new position on the active participation of the epithelium in the formation of anti-infective resistance of the body. The epithelium, recognizing an infectious factor with the help of TLRs, initiates immediate mobilization of mechanisms for its elimination by its own "forces" or by attracting the adaptive immune response elements.
The events in SARS-Cov-2 induced infection follow the next scenario: epithelial cells via TLRs recognize and identify SARS-Cov-2, and after that the information is transmitted to the transcriptional NF- $\kappa \mathrm{B}$, which causes expression of the corresponding genes. Activated in this way, the epithelial cells begin to synthesize various biologically active molecules, including chemokines (cytokines with a chemoattracting effect), resulting in the attraction of macrophages and polymorphic-nuclear leukocytes (neutrophils, basophils, eosinophils) to the site of infection. The activated macrophages and polymorphic-nuclear leukocytes result in phagocytosis of the infectious factor and allocation of their own set of proinflammatory mediators.

Thus, the intracellular infectious factors (viruses, such as SARS-Cov-2), and a number of other infectious agents (pathogens of syphilis, tuberculosis, leprosy, etc.) are recognized by TLRs localized on the internal structures of cells. Due to this, it can be assumed that BCG vaccination protects the body from the pathogenic effects of COVID-19. Apparently, due to this, children are in the low-risk zone of COVID-19 (10). 
Figure 4. Intracellular mechanisms of the activation of cytokine synthesis during stimulation of the TLRs receptor families

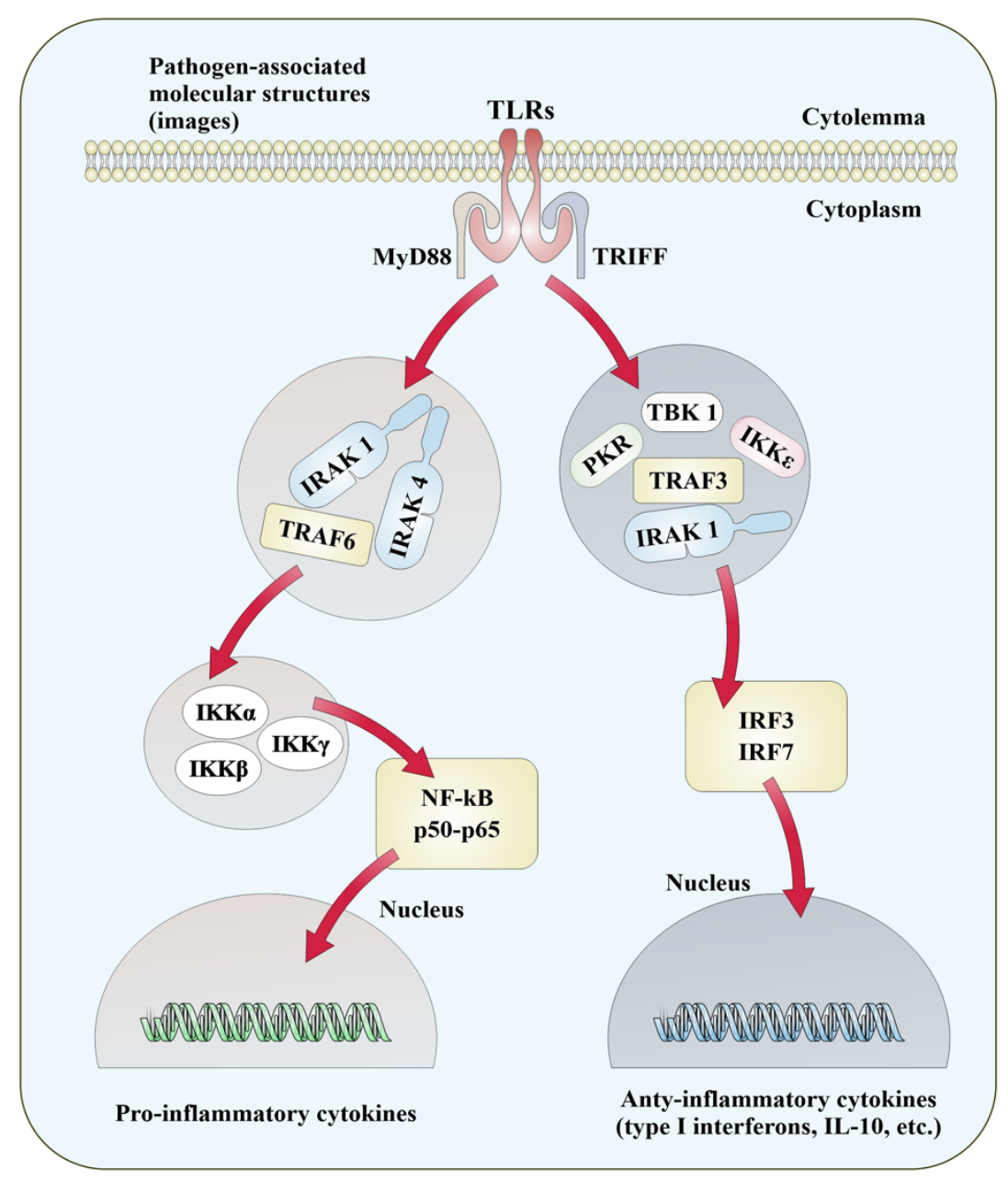

[Comment: I. Pathogenic ligand recognized by the TLR receptor family includes MyD88 or TRIF adapter proteins. MyD88 interacts with members of the IRAK family that mobilizes TRAF6, which transmits the signal to the IKK - complex. Then follows the activation of NF- $\mathrm{BB}($ RelA-p50), its penetration into the nucleus and subsequent activation of proinflammatory cytokine genes. There is possible MyD88 independent signal transmission path via TRIF adapter protein, which transmits a signal to the TBK1 and IKK kinases that are in communication with TRAF3. The subsequent activation of IRF3 and IRF7 leads to their penetration into the nucleus and stimulation of the synthesis of anti-inflammatory cytokines: type I interferons -IFN $\square$ and IFN $\beta$; interleukins: IL-10, etc.. Specifically launched response to the activation of TLR3 synthesis of type I interferons strengthens the antivirus protection. In addition, TLR3 activation causes differentiation and maturation of dendritic cells and thus initiates the adaptive immune responses. II. MyD88-myeloid differentiated factor 88; universal adapter protein; TBK1-serotonin / threonine-kinase is involved in the cascade transmission of signals that lead to the activation of NF- $\mathrm{BB}$ transcription. It was found out, that the TBK-1 protein is, on the one hand, an antiviral factor, and with the other is involved in maintaining the viability of tumor cells. Exposure to this protein by substances which block TBK-1 activity may be a fairly promising component of the antiblastomic therapy, however, it has to be taken into account that the inactivation of TBK-1 reduces the body's ability to resist viral infections infections; TRAF6 is a cytosolic adapter protein associated with the receptor of tumor necrosis factor 6; IRAK1, IRAK4 - cytosolic enzymes of the group of signal kinases [ IRAK4 is the most important kinase in its family; its insufficiency leads to a violation of the immune response to bacterial infection due to the blockage of the TLR4 receptor signaling pathway; mutations in IRAK4 were found in children suffering from persistent pyogenic bacterial infections. The main threat to these patients is Gram-positive bacteria (Staphylococcus aureus, Streptococcus pneumoniae)]; IKKa, IKK $\beta$, IKKy - are inhibitors of the I-kB kinase complex; phosphorylating I-kB destroys it and thus releases NF- $\mathrm{BB}$ and allows it to translocate to the nucleus to activate transcription; TBK1-TANK-is a binding kinase; this is an IKK-related kinase that forms complexes with TRAF2...and activating transcription factor...; TRIF is an adapter protein, which belongs to the group of TIR domain-containing proteins and participates in signal transmission from Toll-like receptors; IRF-transcription factor, which is activated in cells when they are affected by type I interferons: IFN $\square$ and IFNß; IRF "turns on" the transcription of genes that encode synthesis antiviral proteins; PKR-dcRNA (double-stranded RNA) is a dependent protein kinase, induced by interferon, performs at least three functions in the interferon system: participates in providing the antiviral interferon effect; is a mediator of the NF- $\mathrm{B}$ dependent signaling transduction when activating the transcription of the IFN-beta gene; is one of the factors of IFN-dependent inhibition of cell proliferation. A new method of treatment of tumor neoplasms is being developed on the basis of the use of medications that activate protein kinase PKR.]

As previously mentioned, the activated TLRs activate the transcription nuclear factor NF- $\mathrm{BB}$. NF- $\kappa \mathrm{B}$ in an inactive state is linked with a specific inhibitor in the cytoplasm of many cell types, but its expression can be increased due to the response of various stimuli: cytokines, acute phase proteins, regulators of apoptosis and cell proliferation, bacterial toxins, viruses, DNA damage, oxidative stress, and many other factors. The stimulated NF- $\kappa \mathrm{B}$ acquires the ability to move to the nucleus and cause changes in the activity of a large number (more than 150) of a wide variety of target 
genes, which can be involved in the formation of numerous physiological and pathological processes - immune, inflammatory, proliferative, programmed cell death (apoptosis), etc. The activated NF- $\kappa \mathrm{B}$ causes the increase of expression of genes that determine the synthesis of pro-inflammatory cytokines (interleukin(IL)-1 $\beta$, IL-2, IL-6, IL-12, IL-18, tumor necrosis factor (TNF)- $\alpha$, TNF- $\beta$, lymphotoxin alpha (LT- $\alpha$ ), lymphotoxin beta (LT- $\beta$ ), granulocyte colony-stimulating factor (G-CSF)), as well as interferons ( $\beta$ and $\gamma$ ). SARS-CoV2 penetrates the cell using the ACE2 receptor $(11,12)$ and enzyme TMPRSS2. But the most unusual thing was that the ACE2 gene, which encodes the receptor used by SARS-CoV2 to enter human cells, is stimulated by interferon - one of the body's main defence forces when detecting the virus. Interferon actually turns on the ACE2 receptor at higher levels, giving the virus new "portals" to penetrate. Thus, the use of interferon at the stage when the virus actively penetrates human cells can further worsen its condition (13).

The life cycle of a virus with a host consists of the following 5 stages: attachment, penetration, biosynthesis, maturation and release. Once the virus binds to host receptors (attachment), they enter host cells through endocytosis or membrane fusion (penetration). As soon as the viral content is released inside the host cells, the viral RNA enters the nucleus for replication. The viral mRNA is used to create the viral proteins (biosynthesis). Then new viral particles are created (maturation) and released (14).

Coronavirus consists of four structural proteins: spike, membrane, envelop and nucleocapsid (15).

The spike consists of two functional subunits, the S1 subunit is responsible for binding to the host cell's receptor, and the $\mathrm{S} 2$ subunit is responsible for merging viral and cell membranes. ACE2 has been identified as a functional receptor for SARS-CoV (16). The structural and functional research has shown that the outbreak of SARS-CoV-2 is also connected with ACE2 (5,11-13).

The expression of ACE2 is high in lungs, heart, ileum, kidneys, endotheliacytes and bladder (17). In the lungs, ACE2 is highly expressed in the epithelial cells of bronchi. It was shown, that upon the binding of the SARS spike protein to the ACE2 receptor, the whole unit is undergoing proteolysis by TMPRSS2, which leads to the ACE2 cleavage and activation of spike protein $(18,19)$ resulting in penetration of the virus into the target cell. Thus, the cells which express both ACE2 and TMPRSS2 are mostly affected by SARSCoV (20). It was shown that SARS-CoV-2 also needs ACE2 and TMPRSS2 to entry a cell (21). The unique characteristics of SARS-CoV-2 among coronaviruses are the presence of a furin cleavage site at the S1/S2 site. The S1/S2 site was completely cleaved during biosynthesis in sharp contrast to the SARS-CoV spike that was incorporated into the assembly without cleavage, making this virus very pathogenic $(11,18,19,22)$.
Because ACE2 is highly expressed at the apical side of epithelial cells of the lungs in the alveolar space (23), this virus can penetrate inside and destroy them (Figure 5).

Virus (SARS-Cov2) $\rightarrow$ enters the pulmonary tract $\rightarrow$ interacts with Toll-like receptors in aleovocytes $\rightarrow$ activation of NF-kB (nuclear factor kappa B) $\rightarrow$ interferon synthesis $\rightarrow$ activation of ACE2 (receptor of angiotensin converting enzyme) $\rightarrow$ penetration of SARS-Cov2 into a cell (pneumocyte II type) $\rightarrow$ replication of the virus $\rightarrow$ damage of pneumocyte type II and its death $\rightarrow$ disruption of surfactant's synthesis $\rightarrow$ scarring of the alveoli $\rightarrow$ acute respiratory distress syndrome $\rightarrow$ acute respiratory failure

\section{LUNG TISSUE DAMAGE CAUSED BY COVID-19}

SARS-CoV-2 spreads very fast and migrates down the respiratory tract. Unfortunately, around $20 \%$ of the infected patients develop pulmonary infiltrates, and some of them develop a very serious condition (24). Not only SARS-CoV and flu virus, but also SARS-Cov-2 mainly infect pneumocytes type $2(25,26)$. The infected pneumocytes typemainlyhave peripheral and subpleural localization (27). SARS-CoV multiplies in pneumocytes type 2 , releases a large number of viral particles, and the cells undergo apoptosis and die (28), resulting in reduction of synthesis of surfactant. With a deficiency of surfactant, the declination (atelectasis) of some alveoli and overtension of other alveoli with their subsequent rupture occur. This situation is determined by the heterogeneity of the lungs and, consequently, by the different degree of severity of the deficiency of cells-producers of the lungs surfactant (surface-active agent) that occurs in the multiple organ dysfunction syndrome (MODS). The surfactant deficiency also leads to the development of obstructive alveolar hypoventilation due to a decrease in the patency of the lower respiratory tract: their decline, and then - compression (the result of increased transpulmonal pressure due to the need to perform active exhalations to overcome the increased resistance to air flow in the sleeping lower respiratory tract). When surfactant is deficient in the lungs, Laplace's law shows its effect: the smaller the diameter of the vesicle (i.e., the larger the diameter of the alveoli, etc.), the greater the surface tension of the liquid and, consequently, the air pressure in this bubble. If there is a capacity between the bubbles, the air will move along the pressure gradient to the large-diameter bubbles from the small-diameter bubbles until they disappear. The products of lipooxygenase collapse of the phospholipid components of the surface-active agent- leukotrienes are powerful constrictors of the bronchial tubes. Their excessive formation causes bronchiolospasm, which exacerbates the development of obstructive alveolar hypoventilation. In addition, when surfactant is deficient, recovery of the alveoli and lower respiratory tract is disrupted (for instance, the movement of mucus to the zone of mucociliary transport due to a decrease in the longitudinal gradient of surface pressure). 
Figure 5. The mechanism of penetration of the virus (SARS CoV2) into the cell
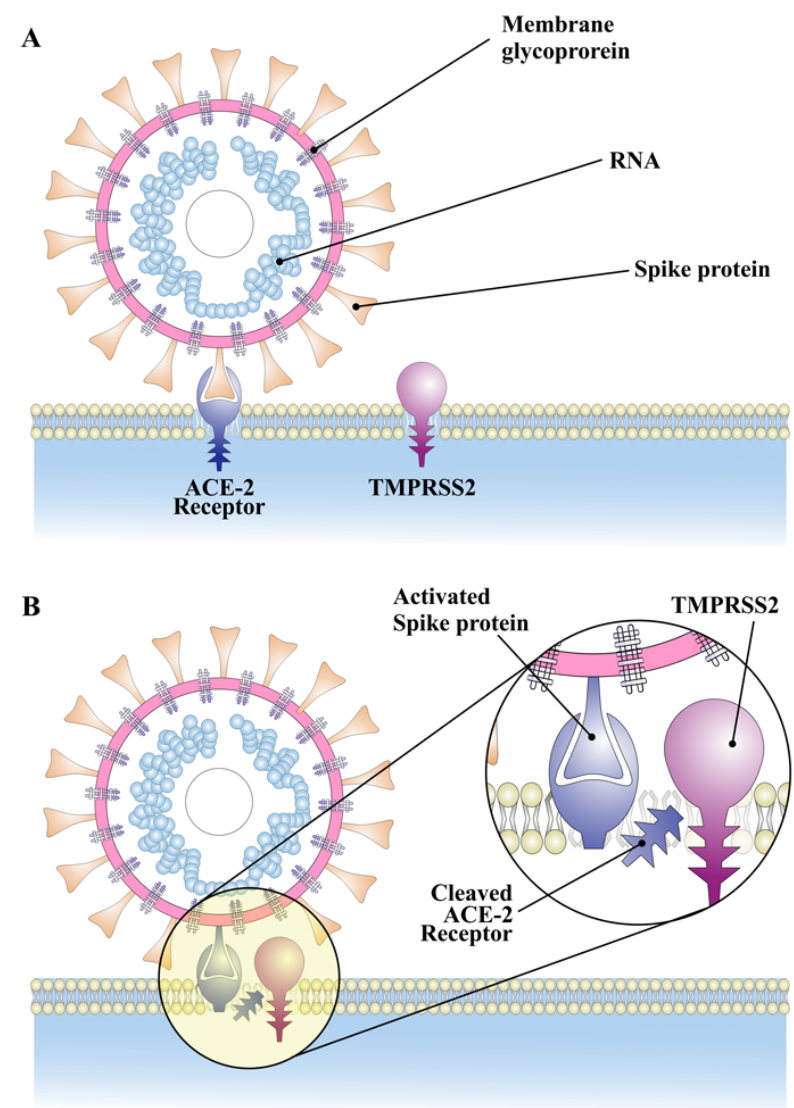

C

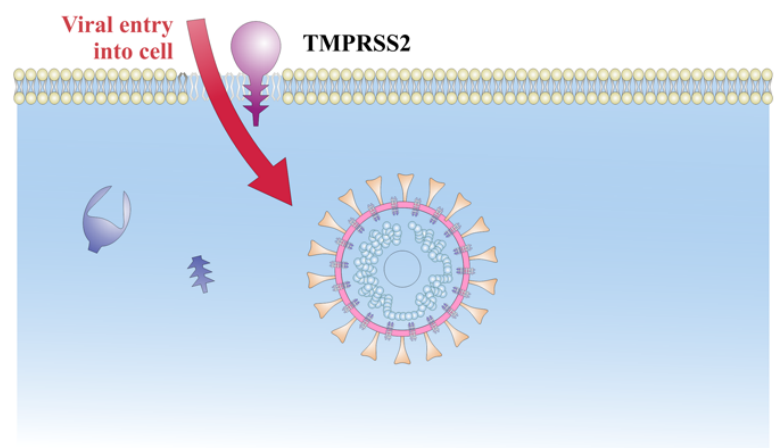

[Comment: (A) Spike proteins on the surface of the coronavirus bind to angiotensin-converting enzyme 2 (ACE-2) receptors on the surface of the target cell; (B) Transmembrane serine protease type II (TMPRSS2) binds and cleaves the ACE-2 receptor. In the process, the spike protein is activated; (C) Splited ACE-2 and activated spike protein help the virus to entry. TMPRSS2 expression increases the cellular uptake of the coronavirus]

Also, under the influence of SARS-CoV-2, the forces of surface tension can cause not only the decline of the alveoli diameter, but also the suction of liquid from the capillaries into the alveoli. The forces of molecular interaction at the liquid/air phase section (water molecules more easily overcome the interphase section) can contribute to fluid retention in the alveoli, resulting in the development of alveolar edema. Thus, the surfactant deficiency is a sufficient factor that leads to the inclusion of all known pathogenetic mechanisms of ARDS.

Virus (SARS-Cov2) $\rightarrow$ enters the respiratory tract $\rightarrow$ damages the type II pneumocytes $\rightarrow$ activation of the type I pneumocytes $\rightarrow$ formation of fibrosis between the alveoli and blood vess els $\rightarrow$ acute respiratory failure

Pneumocytes type 2 are the progenitor cells for pneumocytes type 1 (29). The accumulation of fibrin in the lung blood vessels is facilitated by a decrease in the content of fibrinolysis activators in the pulmonary endothelium. Fibrin can enter the interstitium and lead to the formation of sclerosing alveolitis. The output of fibrin in the lumen of the alveoli is favoured by the increasing defeat of pneumocytes type 2. Extravasates of fibrin in the alveoli cause the formation of hyaline membranes, which are one of the main signs of ARDS.

Thus, the pathologic result of SARS and COVID-19 is a diffused damage of the alveoli with hyaline membranes enriched with fibrin and few multinuclear gigantic cells $(30,31)$. The aberrant wound healing can lead to more severe scarring and fibrosis than the other forms of ARDS.

Virus (SARS-Cov2) $\rightarrow$ enters the respiratory tract $\rightarrow$ interacts with Toll receptors of epithelial cells of the bronchi $\rightarrow$ activation of NF- $\mathrm{KB} \rightarrow$ synthesis of chemokines $\rightarrow$ attraction of macrophages and neutrophils to the submucosa of the bronchi

\section{INFLAMMATORY RESPONSE TO COVID-19 INFECTION}

Epithelial cells firstly use TLRs to recognize and identify SARS-CoV-2. The resulting information is transmitted to the transcriptional nuclear factor NF- $\kappa \mathrm{B}$, which causes the expression of the corresponding genes. Activated in this way, epithelial cells begin to synthesize various biologically active molecules, including chemokines: the growth regulatory oncogenes - GRO $\alpha$, GRO $\beta$, GRO $\gamma$, IL-8 (CXCL8), interferon$\gamma($ IFN- $\gamma$ ), MIP-1 $\alpha$ (macrophage inflammatory protein- $1 \alpha$ ), MIP-1 $\beta$ (macrophage inflammatory protein-1 $\beta$ ), a regulator of activation of normal T-cell expression and secretion (RANTES, CCL5). These cytokines, having a chemoattracting effect, attract macrophages and polymorphonuclear leukocytes to the site of infection.

In addition, epithelial cells produce G-CSF and granulocyte-macrophage colony-stimulating factor (GM-CSF). These colony-stimulating factors induce differentiation of cells of myeloid origin: G-CSF enhances differentiation and proliferation of neutrophils, while GM-CSF stimulates 
proliferation and differentiation of various types of immune progenitor cells. In the lung tissue, GM-CSF causes proliferation and activation of the pulmonary dendritic cells and macrophages. Mice with GM-CSF deficiency are highly sensitive to respiratory viruses. The CXCL8 chemokine purposefully recruits neutrophils to the lung lesion $(32,33)$.

Hyperproduction of cytokines of CXCL8 Chemokines causes recruitment of neutrophils in the affected tissues. Many mediators released by neutrophils themselves are neutrophil chemoattractants, so neutrophils can recruit other neutrophils. In turn, neutrophils produce proinflammatory cytokines and chemokines, and recruit monocytes. High levels of neutrophils in the peripheral blood are associated with an unfavorable prognosis of COVID-19 infection (34). Neutrophils are characterized by a rapid rate of phagocytosis and higher intensity of generation of reactive oxygen species (ROS). Granules of neutrophils contain a fairly wide range of enzymes that are secreted into the extracellular space and can cause tissue destruction (35). Despite the presence of neutrophils in tissues infected with SARS-Cov-2, their role in the clearance of coronaviruses remains unknown.

Epithelial cells, alveolar macrophages, and dendritic cells (DC) are three main components of the innate respiratory immunity (36). DC are located under the epithelium. Macrophages are located on the apical side of the epithelium. DC and macrophages are innate immune cells for fighting viruses, as long as the adaptive immunity is not involved.

Responses mediated by $\mathrm{T}$ cells against coronaviruses were previously considered (5).

DC and macrophages can phagocyte apoptotic cells infected with the virus (37). For example, apoptotic epithelial cells infected with the virus can be phagocytised by DC and macrophages, which leads to presentation of the antigen to $\mathrm{T}$ cells and their infection. Or DC and macrophages may be infected with the virus in the first place. This requires future research.

Virus (SARS-Cov2) $\rightarrow$ interacts with Toll-receptors of epithelial cells of bronchi, macrophages, neutrophils $\rightarrow$ activation of NF- $\kappa$ B (nuclear factor Kappa B) $\rightarrow$ violation of inhibition of cytokine synthesis by the feedback principle $\rightarrow$ synthesis of proinflammatory cytokines in large quantities $\rightarrow$ cytokine "storm" ("storm»)

The processes of biosynthesis of different types of cytokines are carried out according to a single scenario, despite some differences in its implementation. The receptor-mediated effect on cytokine-producing cells of various signals: exo and endogenous factors of infectious and non-infectious nature (including cytokines) initiates the activation of intracellular (cytosolic) mechanisms of their transmission, leading to the activation of transcription factors and, ultimately, changes in the genetic information that cause the expression of biologically active molecules.
The typical process of cytokine biosynthesis and development of the subsequent "cytokine storm" caused by them includes the following consistently implemented mechanisms (Figure 6):

1. Activation of TLRs by SARS-CoV-2.

2. Stimulation of a nuclear transcription factor located in the cytoplasm in combination with its inhibitor. The signal from the activated TLR activates the mechanism of degradation of such an inhibitor, which leads to the release of a transcription factor from its blocking complex.

3. Transcription (this is the first stage of the process of implementing the genetic information). The stimulated transcription factor penetrates the nucleus and binds to specific parts of DNA, which determines the transfer of information from the DNA molecule to the structure of the matrix RNA.

4. Translation is the next stage in the process of implementing the genetic information, during which the synthesis of proteins occurs: cytokines and other biologically active molecules.

5. Release (exocytosis) of formed cytokines from producing cells into the intercellular space and blood vessels.

6. Receptor-mediated effects of newly formed cytokines and other molecules on target cells.

7. Synthesis and isolation of cytokines and other expressed biologically active substances by the activated target cells, which then cause the "phenotypic (target) effects".

Figure 6. Mechanism of cytokine storm development

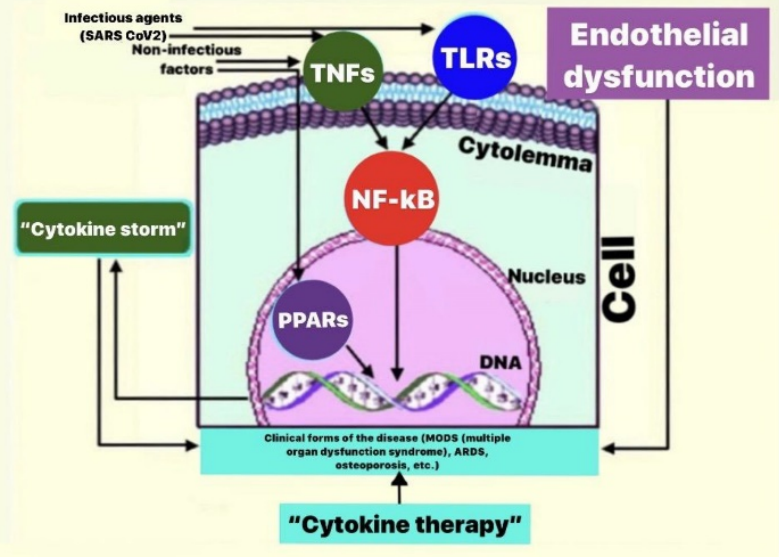

The figure was taken with the permission of the authors from Bolevich SB, Voinov VA. Molecular mechanisms in human pathology. Medical Information Agency.2012;208. (10)

[Comment: TNFs (tumor necrosis factor superfamily); possible without an exaggeration to say that any pathological process and any disease do not develop without the participation of members of this superfamily, which consists of two dozen of cytokines and three dozen of receptors to them. A representative of this TNF $\square$ family, with a wide range of actions, affects the functional activity of immunocompetent 
cells; is the most important mediator of inflammatory and tumor processes, etc. The introduction of inhibitors of this cytokine into clinical practice is considered as one of the the most important achievements of modern medical science and practice. PPARs (peroxisome family of proliferator-activating receptors); these recently discovered receptors play an important role in lipid metabolism and carbohydrates, present a new explanation of the pathogenesis of obesity, insulin- resistance, as well as-many clinical effects of medications, used for the treatment of dyslipidemia, reducing the risk of cardiovascular diseases and their complications in the development of metabolic syndrome. NF- $\mathrm{KB}$ (Kappa B nuclear transcription factor) is a key transcription factor for various numerous cytokine and immuno-regulatory genes that determine the development of the broadest spectrum of immune and inflammatory, gerontological diseases, tumors, viral infections, etc. In combination with its inhibitor, NF- $\kappa B$ is at the intersection of a number of important cascades of biochemical events that lead to the cell activation. TLRs (family of toll-like receptors); the discovery of these receptors has led to the fundamental changes in the perception of the role and mechanisms of formation of the innate immunity, its connection with the adaptive (acquired) immunity, microbiocenosis of the body; has designated prospects for development of more effective prevention and treatment methods of chronic inflammatory and allergic diseases. Endothelial dysfunction is one of the independent risk factors of almost all cardiovascular diseases, including ischemia, atherosclerosis, primary arterial hypertension, as well as diabetes, inflammatory, autoimmune and tumor diseases].

Among many known transcription factors, NF- $\kappa \mathrm{B}$ has received most attention in the medical world. To date, it has been established that NF- $\mathrm{BB}$ is a key transcription factor for genes that determine the development of a wide range of diseases - immune and inflammatory diseases, gerontological diseases, tumors, viral infections, etc.

Up to date, it has been established that NF- $\kappa \mathrm{B}$ is not a single factor, but the whole family of transcription factors that differ in specificity of the DNA-binding and transcriptional activity. This family of NF- $\mathrm{BB}$ includes 5 Rel proteins: RelA (or p65), c-Rel, RelB, Nfkb1 (or p50), and Nfkb2 (or $\mathrm{p} 52$ ). All proteins in the NF- $\mathrm{BB}$ family are homologous to the retroviral cancer protein $\mathrm{v}$-Rel and are therefore classified as $\mathrm{NF}-\kappa \mathrm{B} /$ Rel proteins. Rel proteins are responsible for the interaction of each representative of NF- $\kappa$ Bs with its inhibitor I $\kappa \mathrm{B}$ and binding to DNA. The heterogeneity of the NF- $\kappa$ Bs family allows the cell to subtly regulate the expression of target genes. In the cytoplasm, NF- $\kappa \mathrm{Bs}$ are in an inactive state, which is due to the binding of Rel proteins with inhibitory

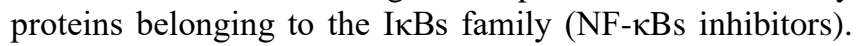
Usually, inactive NF- $\kappa \mathrm{B}$ is associated with one of seven inhibitors: I $\mathrm{B} \alpha, \mathrm{I} \kappa \mathrm{B} \beta, \mathrm{I} \kappa \mathrm{B} \varepsilon, \mathrm{I} \kappa \mathrm{B} \gamma, \mathrm{Bcl} 3, \mathrm{p} 105$, and p100. Each member of the I $\kappa$ Bs family has its own specificity for a particular representative of the NF- $\kappa \mathrm{B}$ family. The combination of NF- $\kappa \mathrm{B}$ with I $\kappa \mathrm{B}$ forms an IKK (inhibitor kinase complex $\mathrm{NF} \kappa \mathrm{B})$. The activation of the IKK kinase family is necessary for the release (activation) of NF-kB: IKK phosphorylates
I $\kappa$. NF- $\kappa B$ released due to degradation of I $\kappa \mathrm{B}$ is translocated to the nucleus. By entering the nucleus, NF- $\kappa B$ stimulates the expression of its $\mathrm{I} \kappa \mathrm{B}$. Then, this newly synthesized (expressed) I $\mathrm{KB}$ molecule translocates into the nucleus and prevents further interaction of NF- $\kappa \mathrm{B}$ with regulatory DNA sites. In other words, there is a negative feedback loop that restricts the activity of NF- $\kappa \mathrm{B}$ by the mechanism of autoregulation.

It can be assumed that SARS-Cov-2 violates the interaction of NF- $\kappa$ B with I $\mathrm{B}$. It inhibits the expression of I $\mathrm{B}$ and thus does not prevent further interaction of NF- $\kappa$ B with regulatory DNA sites. This leads to the uncontrolled formation of pro-inflammatory cytokines.

As it turned out, the functional state of NF- $\kappa \mathrm{B}$ can be controlled not only by I $\kappa \mathrm{Bs}$, but also by other factors. Various ways of activation and suppression of excessive stimulation of NF- $\kappa$ Bs have been established. There are two main variants of sequential events that lead to NF- $\mathrm{B}$ activation: the classic ("canonical") and alternative ("non-canonical") pathways.

The classical signaling pathway is initiated by a large set of different extracellular signals: the pathogen-associated molecular structures that implement their effects with the help of TLR on epithelial cells, macrophages, neutrophils and pro-inflammatory cytokines: TNF- $\alpha$, IL-1 $\beta$, and many other factors.

An alternative signaling pathway is induced by LT- $\alpha$, LT$\beta$, CD40L (differentiation cluster ligand 40), BAFF (factor activating $\mathrm{B}$ - lymphocytes), RANKL (RANKL ligand activating NF- $\kappa \mathrm{B}$ receptors), and apparently other factors (Figure 7).

Figure 7. Signal activation pathways of the NF - kBs family

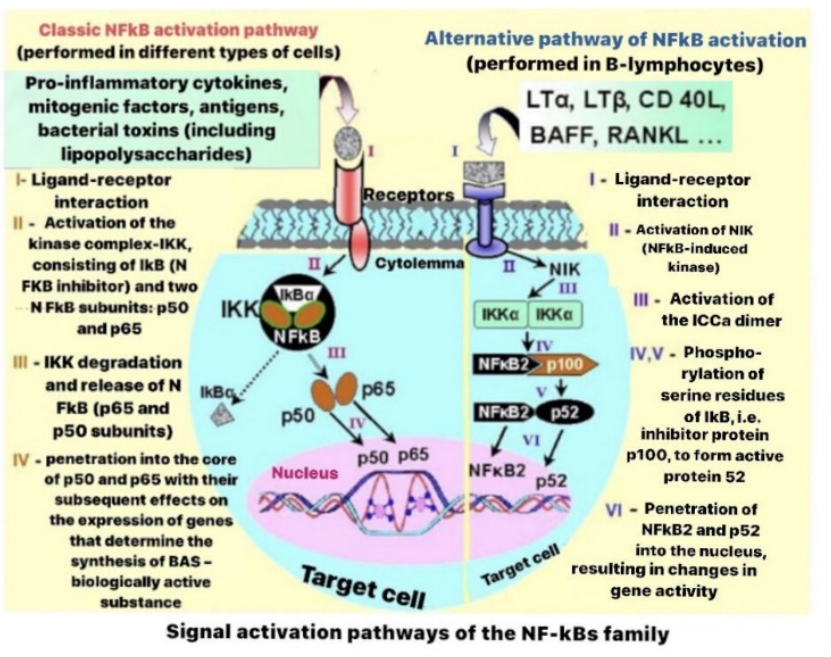

The figure was taken with the permission of the authors from Bolevich SB, Voinov VA. Molecular mechanisms in human pathology. Medical Information Agency. 2012;208. 
These two pathways of the signal transmission from receptors to DNA differ not only in the set of inducing factors, but also in the mechanisms of degradation of members of the IкBs family. Probably, this degradation can be enhanced by SARS-CoV-2.

\section{ROLES OF CYTOKINES IN COVID-19 INFECTION}

COVID-19 disease is accompanied by an extremely high level of production of pro-inflammatory cytokines (IFN- $\alpha$, IFN- $\gamma$, IL-1 $\beta$, IL-6, IL-12, IL-18, IL-33, TNF- $\alpha$, GM-CSF) and chemokines (CCL2, CCL3, CCL5, CXCL8, CXCL9, CXCL10) (38-41). Such increase in the production of proinflammatory cytokines and cytokine reaction observed in SARS-CoV-2 infected patients were called "cytokine storm". These cytokines and chemokines recruit effector immunocytes, causing the development of a local inflammatory response. The characteristic feature of severe forms of disease is a decrease in IL-10 production. The "cytokine storm" is the basis for the development of ARDS and multiple organ failure, which in severe cases of SARS-CoV infection lead to death (42-44). Severe COVID-19 infection is accompanied by significantly higher serum levels of cytokines such as IL$1 \beta$, IL-6, TNF- $\alpha$ and CXCL8. It was found that the risk of death due to the disease is associated with a high level of IL6 in the blood (45-47). It is assumed that the virus begins the second attack, causing the patient's condition to deteriorate about 7-14 days after the onset of the disease. From the appearance of the first symptoms of COVID-19 infection to the development of ARDS it takes about 8 days on average (48).

Ingress of SARS-Cov2 and cytokines into the blood vessels of the lungs $\rightarrow$ increased vascular permeability $\rightarrow$ exit of fluid into the lung tissue $\rightarrow$ non-cardiogenic pulmonary oedema $\rightarrow$ penetration of fluid (exudate) into the alveoli $\rightarrow$ acute respiratory failure

Lung damage is the main cause of both the severity of the course and the fatal outcomes of COVID-19 infection (44). Violations of lung perfusion that occur at the beginning of ARDS development lead to an increase in the permeability of alveolo-capillary membranes due to their hypoxic alterations. This factor, along with a deficiency of surfactant, causes the development of interstitial oedema of the lung tissue, and then the accumulation of fluid in the alveolar space. In addition, after penetration of the SARS-CoV-2 virus into the human body, the production of ACE2 protein is inhibited, which leads to a decrease in the level of ACE2 protein representation, especially in the lung tissues. The imbalance of ACE2 and ACE causes an increase in the concentration of Ang II, which over-activates AT1a receptors in the lungs, leading to an increase in the capillary permeability and development of pulmonary oedema $(49,50)$. Subsequently, in the late period of disease development, an extremely high level of production of pro-inflammatory cytokines (IL-6, IL$1 \beta$, TNF- $\alpha$, etc.) by these cells provides an influx of a large number of monocytes and neutrophils, which increase the phenomena of inflammation and contribute to the development of pulmonary oedema in patients with COVID19. IL-1 $\beta$ and TNF- $\alpha$ induce the activity of hyaluronan synthase 2 (HAS2) in endothelial CD31+ cells, alveolar epithelial EpCAM+ cells of the lungs and fibroblasts, which leads to an excess of hyaluronic acid production and fluid accumulation in the alveolar space (51). The overexpression of hyaluronan plays a key role in the development of inflammation and oedema (52).

Virus (SARS-Cov2) $\rightarrow$ activation of macrophages and neutrophils $\rightarrow$ development of oxidative stress $\rightarrow$ increase in NF- $\kappa \mathrm{B}$ activity $\rightarrow$ increase in cytokine synthesis $\rightarrow$ ROS and cytokines $\rightarrow$ damage to lung tissue $\rightarrow$ pneumonia $\rightarrow$ acute respiratory failure

\section{OXIDATIVE STRESS IN COVID-19 INFECTION}

There is a clear correlation between the markers of oxidative stress and severity of many viral diseases, such as hepatitis C (HCV), but there is very little clinical data for SARS$\mathrm{CoV}$. However, the results obtained on preclinical material indicate that the ROS generation increases and the antioxidant protection decreases, which plays a major role in the pathogenesis of SARS-CoV, as well as in the progression and severity of this respiratory disease. An experimental model on animals with the severe acute respiratory syndrome revealed the increased levels of ROS and reduced the antioxidant protection under the influence of SARS-CoV (53). Some authors suggest that the onset of severe lung damage in patients infected with SARS-CoV depends on the activation of the mechanism of oxidative stress, which is associated with the innate immunity, and activates transcription factors such as NF- $\mathrm{B}$, which leads to the inflammatory response in the body (54). Lin and colleagues (55) have shown that SARS-CoV 3CLpro (viral protease) causes a significant increase in ROS production in HL-CZ cells, which in turn is associated with apoptosis caused by 3CLpro. In this study, the authors demonstrated that SARS-CoV 3CLpro activates the NF- $\mathrm{BB}$-dependent reporter gene, which correlated with an increase in ROS levels in HL-CZ cells. NF- $\kappa B$ sites exist in promoters of apoptosis-related genes and pro-inflammatory genes. Thus, the authors suggest that the NF- $\mathrm{B}$ ROSactivated signal pathway induced by SARS-CoV 3CLpro may be considered a key player in the pathogenesis of SARS$\mathrm{CoV}$ infection. In addition, another SARS-CoV protease, protein 3a, has been associated with the activation of mitochondrial cell death pathways. The proposed mechanism involves oligomerization of Bax and higher levels of p53 in 3aexpressing protein Huh7 cells, which depends on the activation of p38 mitogen-activated protein kinase (MAPK) in these cells (56). The activated (phosphorylated) forms of all MAPK members were found in the cells infected with SARSCoV (57).

The oxidative stress-NF- $\kappa B-T L R$ (mainly TLR4) signaling pathways triggered by the viral pathogens such as SARS$\mathrm{CoV}$ can further enhance the host's inflammatory response, ultimately leading to the acute lung damage. TLR4-TRIF- 
TRAF6 signaling has been identified as a pathogenic pathway that can mediate the severity of acute lung injury. Oxidized phospholipid produced by the lung macrophages can cause a large cytokine formation and lung damage with TLR4-TRIF. Oxidized phospholipids were previously identified in the lungs of humans and animals infected with the SARS virus. In in vivo models, the loss of TLR4 or TRIF expression protected mice from the acute lung damage caused by H5N1. In addition, deletion of Neutrophil Cytosolic Factor 1 (NCF1), which can regulate ROS generation, improves the degree of acute lung damage. Thus, these authors suggest that oxidative stress and innate immunity play a key role in the severity of acute lung damage caused by respiratory viruses (58).

Shao and his colleagues (59) followed the increased regulation of mitochondrial genes and genes that respond to oxidative stress mononuclear cells in the peripheral blood of patients with convalescent SARS-CoV. Some of these genes, including PRDX1, FTH1, and FOS, which are sensitive to oxidative stress, were significantly elevated. These results confirm the relationship between oxidative stress, inflammation, and pathogenesis of SARS-CoV infection.

The severity and risk of death from SARS-CoV-2 or COVID-19 disease were age-related (60). It is well known that the reduction of antioxidant protection and the intensification of free radical processes occur in the aging process $(61,62)$. It has been shown that older mice compared to young adult mice have, with pro-inflammatory cytokines, more severe lung lesions caused by SARS-CoV. It is assumed that the age-related accumulation of free radicals and reduced antioxidant protection cause a violation of the redox balance, which leads to the increased lung damage. Therefore, aging is associated not only with changes in the adaptive immune response, but also with the pro-inflammatory status. The aged macaques monkeys had a stronger body response to a viral infection than young adult macaques, with an increase in differential expression of inflammation-related genes, with NF$\kappa \mathrm{B}$ as a key factor (63).

Virus (SARS-Cov2) and cytokines $\rightarrow$ damage to endothelial cells of blood vessel (SARS-Cov2 is similar to damage of bronchial epithelial cells but cytokines are directly affected) $\rightarrow$ endothelial dysfunction $\rightarrow$ formation of endothelial cells and release into the blood a large number of procoagulants and proagregants $\rightarrow$ massive thrombosis $\rightarrow$ blockage of small vessels of the lungs, kidneys, heart, liver, and other organs with blood clots $\rightarrow$ violation of microcirculation in these organs $\rightarrow$ violation of their function $\rightarrow$ development of shock $\rightarrow$ multiple organ failure

\section{VIRAL DISRUPTION OF ENDOTHELIAL FUNCTIONS}

COVID-19 disrupts the function of the endothelium (64). In a patient with COVID-19, it is common to find the arterial hypertension (65-69), thrombosis (70-72), kidney illnesses $(73,74)$, emboli in the lungs $(75,76)$, cerebrovascular and neurological disorders $(77,78)$ which proves that the virus disrupts the function of the endothelium (79), on the most important organs in the human body $(80,81)$. Furthermore, cases of Kawasaki illness in children with COVID-19 with developed vasculitis (82), only prove this point of view.

The endothelium is not only the main structural component of intima, which acts as a barrier between the blood and the basal membrane of the vascular wall, but also an active regulator of many vital processes (83). The variety of targeted effects of the "hormonal response" of endothelial cells is based on their ability to synthesize a wide range of biologically active substances that are, for the most part, functional antagonists. The set of these substances includes vasoconstrictors and vasodilators, proaggregant and antiplatelet agents, procoagulants and anticoagulants, mitogens and antimutagenic (84). The "hormonal" activity of the intact endothelium promotes vasodilation, prevents hemocoagulation and thrombosis, and limits the proliferative potential of the vascular wall cells (85). On the other hand, in the case of alterations, such as pathogenetically significant changes in the endothelium, its "hormonal" response, on the contrary, contributes to vasoconstriction, hemocoagulation, thrombosis, proliferative process (86).

Generally, it is possible to distinguish 3 main groups of factors that initiate the "hormonal response" of the endothelium:

a. Hemodynamic factor - the influence of this factor on the functional activity of the endothelium depends on the speed of blood flow, its nature, and the values of blood pressure that cause the development of the so-called "shear stress" (87).

b. "Cellular" (locally formed) biologically active substances, having an autocrine or paracrine type of action. These include degranulation and lysis factors ("release reactions") of adhered and aggregated platelets (thromboplastin, fibrinogen, von Willebrand factor, platelet growth factor, fibronectin, serotonin, ADP, acid hydrolases), products of marginal, wall-mounted leukocytes, primarily neutrophils (adhesive molecules, lysosomal proteases, ROS, leukotrienes, prostaglandins E, etc.), activated mast cells (histamine, serotonin, leukotrienes C4 and D4, platelet activation factor, heparin, proteolytic enzymes, chemotactic and other factors) (88-91).

c. Circulating (distant-formed) biologically active substances that have an endocrine type of action. These include catecholamines, vasopressin, acetylcholine, bradykinin, adenosine, histamine, and many others (92).

The action of mediators and neurohormones is carried out through specific receptors located on the surface of endothelial cells. A number of substances are able to act on endothelial cells bypassing the receptors, directly through the cell membrane. 
ACE2 receptors are also expressed by endothelial cells $(93,94)$. It should be noted that all factors involved in the penetration of SARS-CoV-2 into the cell such as sialic acid, transmembrane serine protease 2 (TMPRSS2), inducer of extracellular matrix metalloproteinase (CD147) and cathepsins $\mathrm{B}$ and $\mathrm{L}$ are also expressed in endothelial cells (95-100).

It can be assumed that SARS-CoV2 entering the endothelial cell causes the activation of $\mathrm{NF}-\kappa \mathrm{B}$ (directly or through the increased amount of ROS caused by it). In addition, cytokines have a damaging and stressful effect on the endothelial cell, and it is perceived by mechanosensors located on its luminal surface. These include ion channels $\left(\mathrm{K}^{+}, \mathrm{Ca}^{+}, \mathrm{Na}^{+}\right.$, $\left.\mathrm{Cl}^{-}\right)$, caveoles, NADPH oxidases, cell membrane proteoglycans and G-proteins. G-proteins are not only mechanosensors, but, first of all, universal intermediaries in the transmission of hormonal and neurotransmitter signals from the cell membrane receptors to effector proteins that cause targeted responses. In addition, stress signals can be transmitted through the mechanosensory complex, including PECAM and Flk-1, as well as - mediated by the adhesive molecules integrins and cadherins. The activated sensors transmit signals further along various intracellular pathways ("signal cascades") (Figure 8).

Figure 8. Main endothelial mechanosensors of stress factors and intracellular mechanisms of their implementation

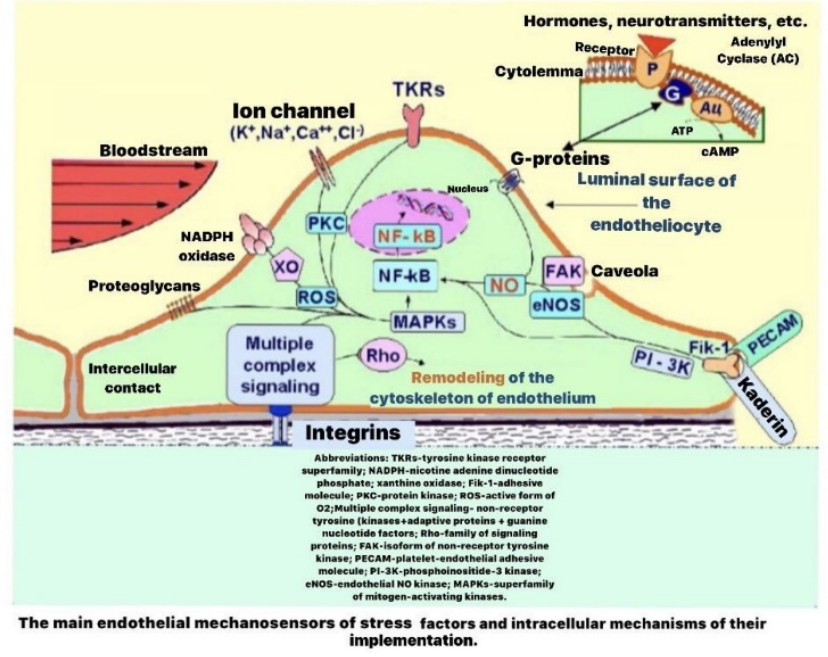

The figure was taken with the permission of the authors from Bolevich SB, Voinov VA. Molecular mechanisms in human pathology. Medical Information Agency.2012;208. (10)

In recent years, there has been an increased interest in the problem of stress signal transmission, since there is evidence of the existence of specialized intracellular stress-activated signaling pathways, which include the stress-activated protein kinases. Such enzymes can be activated by a variety of factors, including oxidative stress, UV radiation, osmotic stress, integrins, TNF- $\alpha$, and others. Particularly important in the transmission of stress signals are SAPK (stress-activated protein kinases) of the MAPKs, namely: JNK-N - terminal kinases (JNKs) and p38 kinase. Stimulated integrins, and many other factors exercise their influence through this multi-component signaling complex. MAPKs performs regulatory phosphorylation of the nuclear transcription factors, cell cytoskeleton proteins, and signal transfer proteins at the last stages of this process. Thus, the activity of NF$\kappa$ Bincreases sharply (87). In the final accounts, theendothelial cell begins to produce a large number of pro-aggregant and vasoconstrictors, which leads to higher mortality rates (71,100,101).

Patients with the fatal outcomes were found to have significantly higher levels of D-dimer and fibrin degradation product and a longer prothrombin time compared to those who survived the admission (102). Moreover, a significant decrease in the fibrinogen levels and antitrobin activity was observed in patients with the fatal outcome at the late stages of hospitalization, which is compatible with the clinical diagnosis of disseminated intravascular coagulation (DICsyndrome) (103). It should be noted that when DIC syndrome is caused by a systemic infection, it is characterized by an acute systemic excessive inflammatory response closely related to the endothelial dysfunction (104).

The endothelial dysfunction induced by SARS-CoV2 leads to massive thrombosis and blockage of small vessels of the lungs, kidneys, heart, liver, and other organs with microthrombs, which causes a violation of microcirculation in these organs and, accordingly, a violation of their function. Microthrombosis of the pulmonary microvessels leads to the impaired lung perfusion. Indeed, the pulmonary endothelium is a fundamental barrier between the blood and interstitial tissue and performs vital regulatory functions. In particular, endothelial cells make up one-third of the lung cell population (105), but the violation of pulmonary endothelium even increases the severity of influenza-like illness (ILI) (106). COVID-19 patients with massive microthrombosis and impaired microcirculation experience a state of shock with multiple organ failure, which can ultimately lead to death.

Virus (SARS-Cov2) and cytokines $\rightarrow$ damage to endotheliocytes of blood vessels $\rightarrow$ endothelial dysfunction $\rightarrow$ formation of endothelial cells and release into the blood of a large number of procoagulants and proagregants $\rightarrow$ massive thrombosis $\rightarrow$ blockage of large vessels of the brain (development of strokes), heart (development of heart attacks), lower extremities (development of gangrene of the lower extremities) $\rightarrow$ multiple organ failure

The endothelial dysfunction can be an independent cause of circulatory disorders in the organ, since it often provokes angiospasm or vascular thrombosis $(108,109)$, which in particular, is observed in some forms of ischemia. Deep vein thrombosis and/or pulmonary embolism have previously been described in patients with ILI (110-114) as well as the cases of thrombosis in patients with influenza associated with pneumonia (115-117). 
When the endothelium is damaged in patients with COVID-19, its surface turns from antithrombotic to prothrombotic. In the case of exposure of the proadgesive surface of the subendothelial matrix, its components-adhesive proteins (von Willebrand factor, collagen, fibronectin, thrombospondin, fibrinogen, etc.) are immediately included in the formation of the primary (vascular-platelet) thrombus and consequently hypercoagulation. The endothelium is able to produce and secrete a number of substances, such as catecholamines, endotheliin-1, Ang-2 that have a vasoconstrictive effect. Ang-2 increases the permeability of microvessels $(118,119)$, induces the transcription of tissue factor in endothelial cells (120-122) and activates thrombocytes (123-125). Moreover, Ang-2 can induce the outgo of few components of the complement system in endothelial cells (126-129) which additionally proves the main role of endothelium in the pathogenesis of venous and arterial thrombosis in patients with COVID-19 (130,131). Thus, patients with COVID 19 may be complicated by stroke, heart attack or thrombosis of the lower limb arteries with the development of multiple organ failure.

Virus (SARS-Cov2) $\rightarrow$ interacts with Toll receptors of the body's cells $\rightarrow$ the formation of a huge number of cytokines (cytokine "storm") $\rightarrow$ cytokine sepsis $\rightarrow$ multiple organ failure

\section{MULTIPLE ORGAN DYSFUNCTION SYNDROME (MODS) INDUCED BY COVID-19}

In general terms, the pattern of sepsis-induced MODS development in COVID-19 is shown in Figure 9. When SARSCoV-2 enters the body, it is recognized by a family TLRs that trigger the production of cytokines. The key cytokines that mediate the septic form of MODS are TNF- $\alpha$, IL-1 and IL-6, whose massive release from monocytes, macrophages, neutrophils and other cells is provoked by SARS CoV-2. The isolated introduction of at least one of these cytokines into the body without the participation of any microorganisms gives a complete clinical picture characteristic of sepsis. It is noteworthy that by binding or blocking the excess TNF- $\alpha$ and IL-1, for example, with specific antibodies, it is possible to remove most of the phenomena of acute infectious damage and prevent the development of septic shock. Cytokines mediate their action by activating NF- $\kappa$ B. It was noted above that currently NF- $\mathrm{KB}$ is considered as the main transcription factor for genes that determine the development of a wide range of diseases of an immune and inflammatory nature, gerontological diseases, tumors, viral infections. Subsequent to the activation of NF- $\kappa \mathrm{B}$ and other transcription factors, changes in the genetic program determine the stimulation of synthesis of "early" cytokines, and then "late" cytokines and other mediators of the systemic inflammatory response. Mediators cause various metabolic and functional changes in the body, manifesting the development of septic, as well as other, i.e. aseptic forms of MODS. In the genesis of acute vascular insufficiency - one of the main pathogenetic components of this syndrome, a special role is assigned to nitrogen oxide, the concentration of which can increase tenfold as a result of stimulation of macrophages TNF- $\alpha$, IL-1 and other factors. It was found that the introduction of NO to experimental animals can lead to a condition that simulates sepsis. One of the main pathogenetic components of this form of pathology is a violation of microcirculation, which first leads to the development of systemic capillary-trophic insufficiency, and then, to a large extent, determines the formation of MODS.

First of all, the "shock wave" of inflammatory mediators takes over the lungs - the "biochemical filter" of blood on the way to the brain, which leads to their damage or, according to modern nomenclature, to the development of acute lung injury syndrome, which is considered as a "typical pacemaker" of MODS.

The complex of factors that makes up the pathogenetic basis of various clinical symptoms of MODS includes the acute respiratory failure (generalized hypoxia), microcirculation disorders (capillary-trophic insufficiency), endothelial dysfunction (violation of the regulation of the vascular lumen and haemostasis system), enteral insufficiency (intestinal auto-intoxication syndrome, malabsorption syndrome), changes in the metabolism (hypermetabolism syndrome, autocatabolism syndrome), encephalopathy (disorders of CNS function).

Figure 9. Pathogenesis of septic multiple organ failure

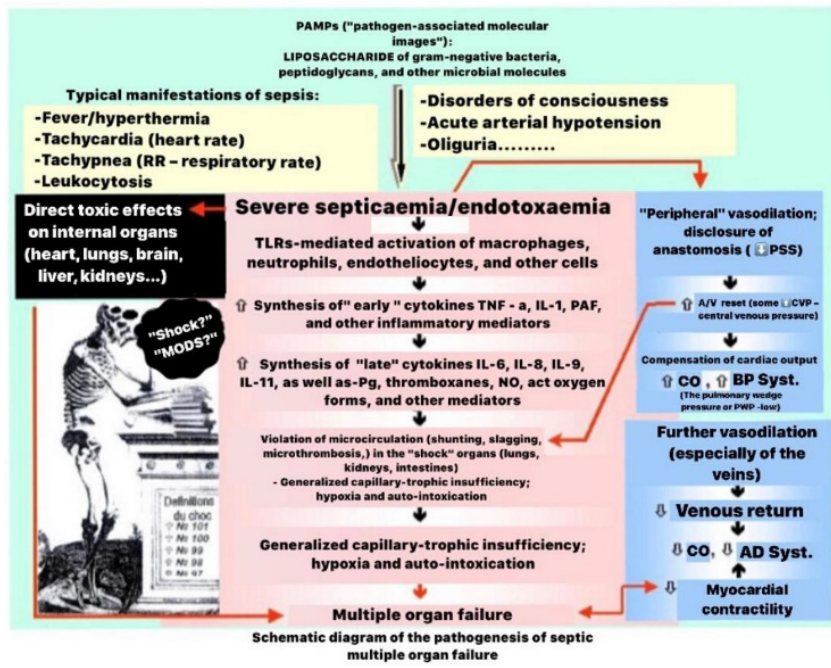

The figure was taken with the permission of the authors from Bolevich SB, Voinov VA. Molecular mechanisms in human pathology. Medical Information Agency.2012;208. (10)

SARS-CoV-2 can cause a local organ/tissue damage or have a generalized damaging effect on the body. In the first case, the inflammation occurs - a "locally flowing" process, which can be adequate, classical: SARS-CoV-2 and altered cells/tissues are blocked, inactivated and removed from the body, which excludes the possibility of generalization of the process, or - inadequate, i.e. with severe tissue damage, insufficient restrictive function of inflammation, excessive formation and massive output of mediators of this process in the 
systemic bloodstream. "Flooding" of the blood with various biologically active substances occurs not only in conditions of the inadequate inflammation, but also accompanies more or less pronounced generalized damage to the body. Based on the data on the existence of mediators between damaging factors and phenotypic changes caused by them, the body develops a "systemic inflammatory response syndrome" - SIRS (the result of the action of pro - inflammatory mediators) and a "compensatory systemic anti-inflammatory response" CARS, as the result of the action of anti-inflammatory mediators.

The excessive content of biologically active substances in the blood is the cause of severe lung damage. This is due to the fact that along with providing the gas exchange, the lungs perform a number of non-respiratory (including metabolic) functions. Quite intensive lung metabolism is primarily due to the neural secretory activity of apudocytes (approximately 40 types of APUD cells were found in the lungs). It should be noted that the metabolic function of the lungs largely depends on the state of the endothelial cells of the small circulatory vessels. Biologically active substances synthesized by apudocytes of a peptide nature affect the vascular tone and permeability of vascular walls, heart function, activity of the gastrointestinal tract, metabolism, excitability of membranes, etc. In the lungs, there is not only synthesis, but destruction (inactivation) of a number of substances, including-norepinephrine, angiotensin-1, etc. This "cleansing" ("barrier") function of the lungs turns them into a kind of "biochemical filter" that protects various organs, primarily the brain from the excessive amount of biologically active substances that have entered the bloodstream. That is why the lungs received the status of "shock organ". In the context of MODS development, the lungs are under the "pressure" of a large number of SIRS and CARS mediators. In this case, the cells of the lung tissue occupy the first line of defence, taking on the "impact of biochemical aggression factors", which leads to a disorder of their metabolic activity, characterized, in particular, by the development of surfactant deficiency and, accordingly, the acute respiratory failure. The resulting hypoxia of various organs and tissues determines the generalized de novo synthesis of various biologically active substances and their release into the systemic bloodstream. This second "humoral wave" of active molecules, along with the neuro-endocrine response to damaging effects, causes further systemic changes in the body, which can result in the formation of MODS.

Mediators of the humoral component of the systemic response in the conditions of MODS development (their total number is in the hundreds) are: cytokines, components of the complement system, products of arachidonic acid metabolism, platelet activation factor, histamine, cellular adhesive molecules, toxic oxygen metabolites, components of the kallikrein - kinin system, and many others.

The greatest attention in the aspect of MODS pathogenesis is paid to cytokines. Strictly speaking, the pathogenetic basis of MODS is not a systemic inflammatory reaction, but an imbalance between the pro and anti-inflammatory capabilities of the cytokines: both the predominance of pro-inflammatory and anti-inflammatory potential equally determine the development of MODS. The balance of these capabilities is determined not only by the content of pro and antiinflammatory cytokines, but also by other factors mentioned above:

a. the number of membrane-bound cytokine receptors, which is determined by the balance between their biosynthesis and use;

b. the quality of these receptors (they can be inactivated by ligand-cytokine antagonists or antireceptor antibodies);

c. the number of soluble receptors ("trap receptors") which naturally increases in conditions of the increased proteolytic activity of the blood.

In addition, the effects of cytokines depend on the reactivity of target cells: genetic defects in the synthesis of biologically active molecules in them in the presence of a cytokine signal.

One of the characteristics of MODS is the phase of development of this syndrome. Despite the absence of a single, agreed point of view on the pathogenesis of MODS, the above-mentioned concept of a "three-phase response" seems quite convincing from a pathophysiological point of view.

In fact, the initiation of MODS is associated with the natural development of the system's protective and adaptive response, which consists of two components: neuroendocrine (stress response) and humoral (mainly "cytokine" response). From the pathophysiological point of view, the selection of such stage does not cause any doubt, as well as its perfectly adequate name - "phase of induction". This system response induces the inclusion of adaptive mechanisms aimed at mobilization, redistribution, and adequate use of energy and plastic resources in order to contain the scale of alterations, creating unfavourable conditions for various pathogenic infectious factors. The pathogenetic basis of such mechanisms consists of systemic changes in the metabolism. Therefore, the next stage of MODS development is called the "metabolic response phase". At this stage, there are various changes of a functional nature, which, on the one hand, are aimed at providing the metabolic response, and, on the other, these changes are not the "central pathogenetic event" of this phase of MODS. An exception to this statement are changes (functional and organic) in the gastrointestinal tract that occur in connection with the refusal of the body from the services of the digestive system due to the transition to more accessible endogenous food reserves. The resulting damage to the gastrointestinal tract determines the development of malabsorption syndrome and intestinal auto-intoxication syndrome, which cause further development and severity of MODS. This final stage of the formation of this syndrome is called the "phase of secondary autoagression", because it is determined not so much by etiological as pathogenetic factors of MODS. This is, in its most general form, the three-phase 
concept of MODS pathogenesis which occurs under the influence of SARS-CoV-2.

\section{CONCLUSION}

In general, the introduction of SARS-CoV-2 into epithelial cells (skin, lungs, trachea, bronchi, stomach, intestines, etc.), blood, and endothelium of the body causes a local and systematic inflammatory response to damage at the first stage. The key component of this phase (induction) of the response is "cytokine storm" or more precisely - cytokine imbalance.

\section{REFERENCES}

1. Ksiazek TG, Erdman D, Goldsmith CS, Zaki SR, Peret T, Emery S, Tong S, Urbani C, Comer JA, Lim W, Rollin PE, Dowell SF, Ling AE, Humphrey CD, Shieh WJ, Guarner J, Paddock CD, Rota P, Fields B, DeRisi J, Yang JY, Cox N, Hughes JM, LeDuc JW, Bellini WJ, Anderson LJ; SARS Working Group. A novel coronavirus associated with severe acute respiratory syndrome. N Engl J Med. 2003;348(20):1953-66.

2. Zheng M, Gao Y, Wang G, Song G, Liu S, Sun D, Xu $\mathrm{Y}$, Tian Z. Functional exhaustion of antiviral lymphocytes in COVID-19 patients. Version 2. Cell Mol Immunol. 2020;17(5):533-535.

3. Zhang J, Litvinova M, Wang W, Wang Y, Deng X, Chen X, Li M, Zheng W, Yi L, Chen X, Wu Q, Liang Y, Wang $\mathrm{X}$, Yang J, Sun K, Longini IM Jr, Halloran ME, Wu P, Cowling BJ, Merler S, Viboud C, Vespignani A, Ajelli $\mathrm{M}, \mathrm{Yu} \mathrm{H}$. Evolving epidemiology and transmission dynamics of coronavirus disease 2019 outside Hubei province, China: a descriptive and modelling study. Lancet Infect Dis. 2020:S1473-3099(20)30230-9.

4. Li Q, Guan X, Wu P, Wang X, Zhou L, Tong Y, Ren R, Leung KSM, Lau EHY, Wong JY, Xing X, Xiang N, Wu Y, Li C, Chen Q, Li D, Liu T, Zhao J, Liu M, Tu W, Chen C, Jin L, Yang R, Wang Q, Zhou S, Wang R, Liu H, Luo Y, Liu Y, Shao G, Li H, Tao Z, Yang Y, Deng Z, Liu B, Ma Z, Zhang Y, Shi G, Lam TTY, Wu JT, Gao GF, Cowling BJ, Yang B, Leung GM, Feng Z. Early Transmission Dynamics in Wuhan, China, of Novel Coronavirus-Infected Pneumonia. N Engl J Med. 2020;382(13):1199-1207.

5. Channappanavar R, Zhao J, Perlman S. T cell-mediated immune response to respiratory coronaviruses. Immunol Res. 2014;59(1-3):118-28.

6. Rabi FA, Al Zoubi MS, Kasasbeh GA, Salameh DM, AlNasser AD. SARS-CoV-2 and Coronavirus Disease 2019: What We Know So Far. Pathogens. 2020;9(3):231.

7. Wan Y, Shang J, Graham R, Baric RS, Li F. Receptor Recognition by the Novel Coronavirus from Wuhan: an Analysis Based on Decade-Long Structural Studies of SARS Coronavirus. J Virol. 2020;94(7):e00127-20.

8. Hoffmann M, Kleine-Weber H, Schroeder S, Krüger N, Herrler T, Erichsen S, Schiergens TS, Herrler G, Wu
The pathogenetic basis of this phase of SARS-Cov2 infection is a disruption of the cellular, organ tissue and system adaptive reactions of the body. The next stage is developing a related network of events (each patient individually) which results in the failure of the body systems (respiratory, blood circulation, hemostasis, endocrine and neural), with development of different periodical complications and subsequent insufficiency of the circulatory, respiratory systems (ARDS, ALI), hemostasis (DIC), digestion (malabsorption syndrome), endocrine and nervous (shock, coma) problems resulting in the MODS.

NH, Nitsche A, Müller MA, Drosten C, Pöhlmann S. SARS-CoV-2 Cell Entry Depends on ACE2 and TMPRSS2 and Is Blocked by a Clinically Proven Protease Inhibitor. Cell. 2020 Apr 16;181(2):271-280.e8.

9. Xiao L, Sakagami H, Miwa N. ACE2: The key Molecule for Understanding the Pathophysiology of Severe and Critical Conditions of COVID-19: Demon or Angel? Viruses. 2020;12(5):E491.

10. Bolevich SB, Voinov VA. Molecular mechanisms in human pathology. Medical Information Agency. 2012;208.

11. Walls AC, Park YJ, Tortorici MA, Wall A, McGuire AT, Veesler D. Structure, Function, and Antigenicity of the SARS-CoV-2 Spike Glycoprotein. Cell. 2020; 181(2):281-292.e6.

12. Letko M, Marzi A, Munster V. Functional assessment of cell entry and receptor usage for SARS-CoV-2 and other lineage $\mathrm{B}$ betacoronaviruses. Nat Microbiol. 2020;5(4):562-569.

13. Ziegler CGK, Allon SJ, Nyquist SK, Mbano IM, Miao VN, Tzouanas CN, Cao Y, Yousif AS, Bals J, Hauser BM, Feldman J, Muus C, Wadsworth MH 2nd, Kazer SW, Hughes TK, Doran B, Gatter GJ, Vukovic M, Taliaferro F, Mead BE, Guo Z, Wang JP, Gras D, Plaisant M, Ansari M, Angelidis I, Adler H, Sucre JMS, Taylor CJ, Lin B, Waghray A, Mitsialis V, Dwyer DF, Buchheit KM, Boyce JA, Barrett NA, Laidlaw TM, Carroll SL, Colonna L, Tkachev V, Peterson CW, Yu A, Zheng HB, Gideon HP, Winchell CG, Lin PL, Bingle CD, Snapper SB, Kropski JA, Theis FJ, Schiller HB, Zaragosi LE, Barbry P, Leslie A, Kiem HP, Flynn JL, Fortune SM, Berger B, Finberg RW, Kean LS, Garber M, Schmidt AG, Lingwood D, Shalek AK, Ordovas-Montanes J; HCA Lung Biological Network. Electronic address: lung-network@humancellatlas.org; HCA Lung Biological Network. SARS-CoV-2 Receptor ACE2 Is an Interferon-Stimulated Gene in Human Airway Epithelial Cells and Is Detected in Specific Cell Subsets across Tissues. Cell. 2020;181(5):1016-1035.e19.

14. Yuki K, Fujiogi M, Koutsogiannaki S. COVID-19 pathophysiology: A review. Clin Immunol. 2020;215:108427.

15. Bosch BJ, van der Zee R, de Haan CA, Rottier PJ. The coronavirus spike protein is a class I virus fusion protein: 
structural and functional characterization of the fusion core complex. J Virol. 2003;77(16):8801-11.

16. Li W, Moore MJ, Vasilieva N, Sui J, Wong SK, Berne MA, Somasundaran M, Sullivan JL, Luzuriaga K, Greenough TC, Choe H, Farzan M. Angiotensin-converting enzyme 2 is a functional receptor for the SARS coronavirus. Nature. 2003;426(6965):450-4.

17. Zou X, Chen K, Zou J, Han P, Hao J, Han Z. Single-cell RNA-seq data analysis on the receptor ACE2 expression reveals the potential risk of different human organs vulnerable to 2019-nCoV infection. Front Med. 2020;14(2):185-192.

18. Glowacka I, Bertram S, Müller MA, Allen P, Soilleux E, Pfefferle S, Steffen I, Tsegaye TS, He Y, Gnirss K, Niemeyer D, Schneider H, Drosten C, Pöhlmann S. Evidence that TMPRSS2 activates the severe acute respiratory syndrome coronavirus spike protein for membrane fusion and reduces viral control by the humoral immune response. J Virol. 2011;85(9):4122-34.

19. Heurich A, Hofmann-Winkler H, Gierer S, Liepold T, Jahn O, Pöhlmann S. TMPRSS2 and ADAM17 cleave ACE2 differentially and only proteolysis by TMPRSS2 augments entry driven by the severe acute respiratory syndrome coronavirus spike protein. J Virol. 2014;88(2):1293-307.

20. Shulla A, Heald-Sargent T, Subramanya G, Zhao J, Perlman S, Gallagher T. A transmembrane serine protease is linked to the severe acute respiratory syndrome coronavirus receptor and activates virus entry. J Virol. 2011 Jan;85(2):873-82.

21. Zhou P, Yang XL, Wang XG, Hu B, Zhang L, Zhang W, Si HR, Zhu Y, Li B, Huang CL et al. Discovery of a novel coronavirus associated with the recent pneumonia outbreak in humans and its potential bat origin. bioRxiv. 2020; doi:10.1101/2020.01.22.914952.

22. Kuba K, Imai Y, Rao S, Gao H, Guo F, Guan B, Huan Y, Yang P, Zhang Y, Deng W, Bao L, Zhang B, Liu G, Wang Z, Chappell M, Liu Y, Zheng D, Leibbrandt A, Wada T, Slutsky AS, Liu D, Qin C, Jiang C, Penninger JM. A crucial role of angiotensin converting enzyme 2 (ACE2) in SARS coronavirus-induced lung injury. Nat Med. 2005;11(8):875-9.

23. Hamming I, Timens W, Bulthuis ML, Lely AT, Navis $\mathrm{G}$, van Goor H. Tissue distribution of ACE2 protein, the functional receptor for SARS coronavirus. A first step in understanding SARS pathogenesis. J Pathol. 2004 Jun;203(2):631-7.

24. Wu Z, McGoogan JM. Characteristics of and Important Lessons From the Coronavirus Disease 2019 (COVID19) Outbreak in China: Summary of a Report of 72314 Cases From the Chinese Center for Disease Control and Prevention. JAMA. 2020. doi: 10.1001/jama.2020.2648.

25. Mossel EC, Wang J, Jeffers S, Edeen KE, Wang S, Cosgrove GP, Funk CJ, Manzer R, Miura TA, Pearson LD, Holmes KV, Mason RJ. SARS-CoV replicates in primary human alveolar type II cell cultures but not in type I-like cells. Virology. 2008;372(1):127-135.

26. Weinheimer VK, Becher A, Tonnies M, Holland G, Knepper J, Bauer TT, Schneider P, Neudecker J, Ruckert
JC, Szymanski K, Temmesfeld-Wollbrueck B, Gruber AD, Bannert N, Suttorp N, Hippenstiel S, Wolff T, Hocke AC. Influenza A viruses target type II pneumocytes in the human lung. J Infect Dis. 2012;206(11):1685-1694.

27. Wu J, Wu X, Zeng W, Guo D, Fang Z, Chen L, Huang $\mathrm{H}, \mathrm{Li}$ C. Chest CT Findings in Patients With Coronavirus Disease 2019 and Its Relationship With Clinical Features. Invest Radiol. 2020;55(5):257-261.

28. Zhang S, Li H, Huang S, You W, Sun H. High-resolution computed tomography features of 17 cases of coronavirus disease 2019 in Sichuan province, China. Eur Respir J. 2020 Apr 30;55(4):2000334.

29. Qian Z, Travanty EA, Oko L, Edeen K, Berglund A, Wang J, Ito Y, Holmes KV, Mason RJ. Innate immune response of human alveolar type II cells infected with severe acute respiratory syndrome-coronavirus. Am J Respir Cell Mol Biol. 2013 Jun;48(6):742-8.

30. Gu J, Korteweg C. Pathology and pathogenesis of severe acute respiratory syndrome. Am J Pathol. 2007;170(4):1136-1147.

31. Xu Z, Shi L, Wang Y, Zhang J, Huang L, Zhang C, Liu S, Zhao P, Liu H, Zhu L, Tai Y, Bai C, Gao T, Song J, Xia P, Dong J, Zhao J, Wang FS. Pathological findings of COVID-19 associated with acute respiratory distress syndrome. Lancet Respir Med. 2020 Apr;8(4):420-422.

32. Gralinski LE, Baric RS. Molecular pathology of emerging coronavirus infections. J Pathol. 2015;235(2):185195.

33. Newton AH, Cardani A, Braciale TJ. The host immune re-sponse in respiratory virus infection: balancing virus clearance and immunopathology. Semin Immunopathol. 2016;38(4):471-482.

34. Liu Y, Yang Y, Zhang C, et al. Clinical and biochemical indexes from 2019-nCoV infected patients linked to viral loads and lung injury. Sci China Life Sci. 2020;63(3):364-374.

35. Genschmer KR, Russell DW, Lal C, et al. Activated PMN Exosomes: Pathogenic Entities Causing Matrix Destruction and Disease in the Lung. Cell. 2019;176(12):113-126.e15.

36. Yoshikawa T, Hill T, Li K, Peters CJ, Tseng CT. Severe acute respiratory syndrome (SARS) coronavirus-induced lung epithelial cytokines exacerbate SARS pathogenesis by modulating intrinsic functions of monocytederived macrophages and dendritic cells. J Virol. 2009;83(7):3039-48.

37. Fujimoto I, Pan J, Takizawa T, Nakanishi Y. Virus clearance through apoptosis-dependent phagocytosis of influenza A virus-infected cells by macrophages. J Virol. 2000 Apr;74(7):3399-403.

38. Huang C, Wang Y, Li X, Ren L, Zhao J, Hu Y, Zhang L, Fan G, Xu J, Gu X, Cheng Z, Yu T, Xia J, Wei Y, Wu W, Xie X, Yin W, Li H, Liu M, Xiao Y, Gao H, Guo L, Xie J, Wang G, Jiang R, Gao Z, Jin Q, Wang J, Cao B. Clinical features of patients infected with 2019 novel coronavirus in Wuhan, China. Lancet. 2020;395(10223):497-506. 
39. Williams AE, Chambers RC. The mercurial nature of neutrophils: still an enigma in ARDS? Am J Physiol Lung Cell Mol Physiol. 2014;306(3):L217-L230.

40. Channappanavar R, Perlman S. Pathogenic human coronavirus infections: causes and consequences of cytokine storm and immunopathology. Semin Immunopathol. 2017 Jul;39(5):529-539.

41. Cameron MJ, Bermejo-Martin JF, Danesh A, Muller MP, Kelvin DJ. Human immunopathogenesis of severe acute respiratory syndrome (SARS). Virus Res. 2008;133(1):13-9.

42. He F, Deng Y, Li W. Coronavirus disease 2019: What we know? J Med Virol. 2020;10.1002/jmv.25766. doi:10.1002/jmv.25766

43. Liu J, Zheng X, Tong Q, et al. Overlapping and discrete aspects of the pathology and pathogenesis of the emerging human pathogenic coronaviruses SARS-CoV, MERS-CoV, and 2019-nCoV. J Med Virol. 2020;92(5):491-494.

44. Xu Z, Shi L, Wang Y, et al. Pathological findings of COVID-19 associated with acute respiratory distress syndrome. Lancet Respir Med. 2020;8(4):420-422.

45. Ruan Q, Yang K, Wang W, Jiang L, Song J. Clinical predic-tors of mortality due to COVID-19 based on an analysis of data of 150 patients from Wuhan, China. Intensive Care Med. 2020; doi:10.1007/s00134-02005991-x;

46. Pyle CJ, Uwadiae FI, Swieboda DP, Harker JA. Early IL-6 signalling promotes IL-27 dependent maturation of regulatory T cells in the lungs and resolution of viral immunopathology. PLoS Pathog. 2017;13(9):e1006640.

47. Rose-John S. Interleukin-6 Family Cytokines. Cold Spring Harb Perspect Biol. 2018;10(2):a028415.

48. Wang D, Hu B, Hu C, et al. Clinical Characteristics of 138 Hospitalized Patients With 2019 Novel Coronavirus-Infected Pneumonia in Wuhan, China. JAMA. 2020;e201585.

49. Kuster GM, Pfister O, Burkard T, et al. SARS-CoV2: should inhibitors of the renin-angiotensin system be withdrawn in patients with COVID-19?. Eur Heart J. 2020;41(19):1801-1803.

50. Wevers BA, van der Hoek L. Renin-angiotensin system in human coronavirus pathogenesis. Future Virol. 2010;5(2):145-161.

51. Bell TJ, Brand OJ, Morgan DJ, et al. Defective lung func-tion following influenza virus is due to prolonged, reversible hy-aluronan synthesis. Matrix Biol. 2019;80:14-28.

52. Heldin P, Lin CY, Kolliopoulos C, Chen YH, Skandalis SS. Regulation of hyaluronan biosynthesis and clinical impact of ex-cessive hyaluronan production. Matrix Biol. 2019;78-79:100-117.

53. van den Brand JM, Haagmans BL, van Riel D, Osterhaus $\mathrm{AD}$, Kuiken T. The pathology and pathogenesis of experimental severe acute respiratory syndrome and influenza in animal models. J Comp Pathol. 2014;151(1):83112.

54. Smith JT, Willey NJ, Hancock JT. Low dose ionizing radiation produces too few reactive oxygen species to directly affect antioxidant concentrations in cells. Biol Lett. 2012;8(4):594-597.

55. Lin CW, Lin KH, Hsieh TH, Shiu SY, Li JY. Severe acute respiratory syndrome coronavirus 3C-like protease-induced apoptosis. FEMS Immunol Med Microbiol. 2006;46(3):375-380.

56. Padhan K, Minakshi R, Towheed MAB, Jameel S. Severe acute respiratory syndrome coronavirus 3a protein activates the mitochondrial death pathway through p38 MAP kinase activation. J Gen Virol. 2008;89(Pt 8):1960-1969.

57. Khomich OA, Kochetkov SN, Bartosch B, Ivanov AV. Redox Biology of Respiratory Viral Infections. Viruses. 2018;10(8):392.

58. Imai Y, Kuba K, Neely GG, et al. Identification of oxidative stress and Toll-like receptor 4 signaling as a key pathway of acute lung injury. Cell. 2008;133(2):235249.

59. Shao H, Lan D, Duan Z, et al. Upregulation of mitochondrial gene expression in PBMC from convalescent SARS patients. J Clin Immunol. 2006;26(6):546-554.

60. Fauci AS, Lane HC, Redfield RR. Covid-19 - Navigating the Uncharted. $\mathrm{N}$ Engl $\mathrm{J}$ Med. 2020;382(13):1268-1269.

61. Gil del Valle L, Gravier Hernández R, Delgado Roche $\mathrm{L}$, et al. Oxidative Stress in the Aging Process: Fundamental Aspects and New Insights. ACS Symposium Series (2015), pp. 177-219;

62. Davies KJ. The Oxygen Paradox, oxidative stress, and ageing. Arch Biochem Biophys. 2016;595:28-32.

63. Smits SL, de Lang A, van den Brand JM, et al. Exacerbated innate host response to SARS-CoV in aged nonhuman primates. PLoS Pathog. 2010;6(2):e1000756.

64. Froldi G, Dorigo P. Endothelial dysfunction in Coronavirus disease 2019 (COVID-19): Gender and age influences. Med Hypotheses. 2020;144:110015..

65. Schiffrin EL, Flack JM, Ito S, Muntner P, Webb RC. Hypertension and COVID-19. Am J Hypertens. 2020;33(5):373-374.

66. Richardson S, Hirsch JS, Narasimhan M, Crawford JM, McGinn T, Davidson KW. The Northwell COVID-19 Research Consortium. Pesenting Characteristics, Comorbidities, and Outcomes among 5700 Patients Hospitalized With COVID-19 in the New York City Area. JAMA. 2020;323(20):2052-2059.

67. Chen $\mathrm{T}, \mathrm{Wu} \mathrm{D}$, Chen $\mathrm{H}$, et al. Clinical characteristics of 113 deceased patients with coronavirus disease 2019: retrospective study. BMJ. 2020;368:m1091.

68. Myers LC, Parodi SM, Escobar GJ, Liu VX. Characteristics of Hospitalized Adults With COVID-19 in an Integrated Health Care System in California. JAMA. 2020;323(21):2195-2198.

69. Guan WJ, Liang WH, Zhao Y, et al. Comorbidity and its impact on 1590 patients with COVID-19 in China: a nationwide analysis. Eur Respir J. 2020;55(5):2000547.

70. Zhou F, Yu T, Du R, et al. Clinical course and risk factors for mortality of adult in patients with COVID-19 in Wuhan, China: a retrospective cohort study. Lancet. 2020;395(10229):1054-1062. 
71. Bikdeli B, Madhavan MV, Jimenez D, et al. COVID-19 and Thrombotic or Thromboembolic Disease: Implications for Prevention, Antithrombotic Therapy, and Follow-Up: JACC State-of-the-Art Review. J Am Coll Cardiol. 2020;75(23):2950-2973.

72. Klok FA, Kruip MJHA, van der Meer NJM, et al. Incidence of thrombotic complications in critically ill ICU patients with COVID-19. Thromb Res. 2020;191:145147.

73. Durvasula R, Wellington T, McNamara E, Watnick S. COVID-19 and Kidney Failure in the Acute Care Setting: Our Experience From Seattle [published online ahead of print, 2020 Apr 8]. Am J Kidney Dis. 2020;S0272-6386(20)30618-1.

74. Ronco C, Reis T. Kidney involvement in COVID-19 and rationale for extracorporeal therapies. Nat Rev Nephrol. 2020;16(6):308-310.

75. Rotzinger DC, Beigelman-Aubry C, von Garnier C, Qanadli SD. Pulmonary embolism in patients with COVID-19: Time to change the paradigm of computed tomography. Thromb Res. 2020;190:58-59.

76. Poissy J, Goutay J, Caplan M, et al. Pulmonary Embolism in COVID-19 Patients: Awareness of an Increased Prevalence. Circulation. 2020;10.1161/CIRCULATIONAHA.120.047430

77. Aggarwal G, Lippi G, Michael Henry B. Cerebrovascular disease is associated with an increased disease severity in patients with Coronavirus Disease 2019 (COVID19): A pooled analysis of published literature. Int J Stroke. 2020;15(4):385-389.

78. Mao L, Jin H, Wang M, et al. Neurologic Manifestations of Hospitalized Patients With Coronavirus Disease 2019 in Wuhan, China. JAMA Neurol. 2020;e201127.

79. Santulli, G.; Morelli, M.; Gambardella, J. Is Endothelial Dysfunction the Concealed Cornerstone of COVID19? BMJ 2020; 368 doi: 10.1136/bmj.m1091.

80. Cooke, J.P. The endothelium: A new target for therapy. Vasc. Med. 2000, 5, 49-53; Aird, W.C. Endothelium as an organ system. Crit Care Med. 2004, 32, S271-S279;

81. Inagami T, Naruse M, Hoover R. Endothelium as an endocrine organ. Annu Rev Physiol. 1995;57:171-189.

82. Riphagen S, Gomez X, Gonzalez-Martinez C, Wilkinson $\mathrm{N}$, Theocharis P. Hyperinflammatory shock in children during COVID-19 pandemic. Lancet. 2020;395(10237):1607-1608..

83. Wang M, Hao H, Leeper NJ, Zhu L; Early Career Committee. Thrombotic Regulation From the Endothelial Cell Perspectives. Arterioscler Thromb Vasc Biol. 2018;38(6):e90-e95.

84. Godo S, Shimokawa H. Endothelial Functions. Arterioscler Thromb Vasc Biol. 2017;37(9):e108-e114.

85. Kazmi RS, Boyce S, Lwaleed BA. Homeostasis of Hemostasis: The Role of Endothelium. Semin Thromb Hemost. 2015;41(6):549-555.

86. Vanhoutte PM, Shimokawa H, Tang EH, Feletou M. Endothelial dysfunction and vascular disease. Acta Physiol (Oxf). 2009;196(2):193-222.
87. Gimbrone MA Jr, García-Cardeña G. Endothelial Cell Dysfunction and the Pathobiology of Atherosclerosis. Circ Res. 2016;118(4):620-636.

88. Loscalzo J. Oxidative stress in endothelial cell dysfunction and thrombosis. Pathophysiol Haemost Thromb. 2002;32(5-6):359-360.

89. Santulli G. Endothelial cells: The heart attack of the Clones. Sci Transl Med. 2018;10(427):eaar7529.

90. McCormack JJ, Lopes da Silva M, Ferraro F, Patella F, Cutler DF. Weibel-Palade bodies at a glance. J Cell Sci. 2017;130(21):3611-3617.

91. Escher R, Breakey N, Lämmle B. Severe COVID-19 infection associated with endothelial activation. Thromb Res. 2020;190:62.

92. Sorriento D, Santulli G, Del Giudice C, Anastasio A, Trimarco B, Iaccarino G. Endothelial cells are able to synthesize and release catecholamines both in vitro and in vivo. Hypertension. 2012;60(1):129-136.

93. Lovren F, Pan Y, Quan A, et al. Angiotensin converting enzyme-2 confers endothelial protection and attenuates atherosclerosis. Am J Physiol Heart Circ Physiol. 2008;295(4):H1377-H1384.

94. Sluimer JC, Gasc JM, Hamming I, et al. Angiotensinconverting enzyme 2 (ACE2) expression and activity in human carotid atherosclerotic lesions. J Pathol. 2008;215(3):273-279.

95. Yang J, Feng X, Zhou Q, et al. Pathological Ace2-to-Ace enzyme switch in the stressed heart is transcriptionally controlled by the endothelial Brg1-FoxM1 complex. Proc Natl Acad Sci U S A. 2016;113(38):E5628-E5635.

96. Aimes RT, Zijlstra A, Hooper JD, et al. Endothelial cell serine proteases expressed during vascular morphogenesis and angiogenesis. Thromb Haemost. 2003;89(3):561-572.

97. Huang DT, Lu CY, Chi YH, et al. Adaptation of influenza A (H7N9) virus in primary human airway epithelial cells. Sci Rep. 2017;7(1):11300.

98. Vanarsdall AL, Pritchard SR, Wisner TW, Liu J, Jardetzky TS, Johnson DC. CD147 Promotes Entry of Pentamer-Expressing Human Cytomegalovirus into Epithelial and Endothelial Cells. mBio. 2018;9(3):e00781-18.

99. Im E, Venkatakrishnan A, Kazlauskas A. Cathepsin B regulates the intrinsic angiogenic threshold of endothelial cells. Mol Biol Cell. 2005;16(8):3488-3500.

100. Platt MO, Shockey WA. Endothelial cells and cathepsins: Biochemical and biomechanical regulation. Biochimie. 2016;122:314-323.

101. Cai J, Zhong H, Wu J, et al. Cathepsin L promotes Vascular Intimal Hyperplasia after Arterial Injury. Mol Med. 2017;23:92-100.

102. Zhang Y, Xiao M, Zhang S, et al. Coagulopathy and Antiphospholipid Antibodies in Patients with Covid-19. N Engl J Med. 2020;382(17):e38.

103. Zhou B, She J, Wang Y, Ma X. Venous thrombosis and arteriosclerosis obliterans of lower extremities in a very severe patient with 2019 novel coronavirus disease: a case report. J Thromb Thrombolysis. 2020; doi:10.1007/s11239-020-02084-w. 
104. Tang N, Li D, Wang X, Sun Z. Abnormal coagulation parameters are associated with poor prognosis in patients with novel coronavirus pneumonia. J Thromb Haemost. 2020;18(4):844-847.

105. Lin L, Lu L, Cao W, Li T. Hypothesis for potential pathogenesis of SARS-CoV-2 infection-a review of immune changes in patients with viral pneumonia. Emerg Microbes Infect. 2020;9(1):727-732.

106. Iba T, Levy JH, Warkentin TE, et al. Diagnosis and management of sepsis-induced coagulopathy and disseminated intravascular coagulation. J Thromb Haemost. 2019;17(11):1989-1994.

107. Zeng H, Pappas C, Belser JA, et al. Human pulmonary microvascular endothelial cells support productive replication of highly pathogenic avian influenza viruses: possible involvement in the pathogenesis of human H5N1 virus infection. J Virol. 2012;86(2):667-678.

108. Maniatis NA, Orfanos SE. The endothelium in acute lung injury/acute respiratory distress syndrome. Curr Opin Crit Care. 2008;14(1):22-30.

109. Schulz C, Engelmann B, Massberg S. Crossroads of coagulation and innate immunity: the case of deep vein thrombosis. J Thromb Haemost. 2013;11 Suppl 1:233241.

110. Abret N, Britton GJ, Gruber C, Hegde S, Kim J, et al. The Sinai Immunology Review Project. Immunology of COVID-19: Current state of the science. Immunity. 2020.

111. Lee N, Hui D, Wu A, et al. A major outbreak of severe acute respiratory syndrome in Hong Kong. N Engl J Med. 2003;348(20):1986-1994.

112. Wong RS, Wu A, To KF, et al. Haematological manifestations in patients with severe acute respiratory syndrome: retrospective analysis. BMJ. 2003;326(7403):1358-1362.

113. Xiang-Hua Y, Le-Min W, Ai-Bin L, et al. Severe acute respiratory syndrome and venous thromboembolism in multiple organs. Am J Respir Crit Care Med. 2010;182(3):436-437.

114. de Wit E, van Doremalen N, Falzarano D, Munster VJ. SARS and MERS: recent insights into emerging coronaviruses. Nat Rev Microbiol. 2016;14(8):523-534.

115. Bunce PE, High SM, Nadjafi M, Stanley K, Liles WC, Christian MD. Pandemic H1N1 influenza infection and vascular thrombosis. Clin Infect Dis. 2011;52(2):e14e17.

116. Hüzmeli C, Saglam M, Arıkan A, Doner B, Akıncı G, Candan F. Infrarenal Aorta Thrombosis Associated with H1N1 Influenza A Virus Infection. Case Rep Infect Dis. 2016;2016:9567495.

117. Ishiguro T, Matsuo K, Fujii S, Takayanagi N. Acute thrombotic vascular events complicating influenza-associated pneumonia. Respir Med Case Rep. 2019;28:100884.

118. Williams B, Baker AQ, Gallacher B, Lodwick D. Angiotensin II increases vascular permeability factor gene expression by human vascular smooth muscle cells. Hypertension. 1995;25(5):913-917.
119. Victorino GP, Newton CR, Curran B. Effect of angiotensin II on microvascular permeability. J Surg Res. 2002;104(2):77-81.

120. Dielis AW, Smid M, Spronk HM, et al. The prothrombotic paradox of hypertension: role of the renin-angiotensin and kallikrein-kinin systems. Hypertension. 2005;46(6):1236-1242.

121. Watanabe T, Barker TA, Berk BC. Angiotensin II and the endothelium: diverse signals and effects. Hypertension. 2005;45(2):163-169.

122. Celi A, Cianchetti S, Dell'Omo G, Pedrinelli R. Angiotensin II, tissue factor and the thrombotic paradox of hypertension. Expert Rev Cardiovasc Ther. 2010;8(12):1723-1729.

123. Jagroop IA, Mikhailidis DP. Angiotensin II can induce and potentiate shape change in human platelets: effect of losartan. J Hum Hypertens. 2000;14(9):581-585.

124. Ding YA, MacIntyre DE, Kenyon CJ, Semple PF. Angiotensin II effects on platelet function. J Hypertens Suppl. 1985;3(3):S251-S253.

125. Larsson PT, Schwieler JH, Wallén NH. Platelet activation during angiotensin II infusion in healthy volunteers. Blood Coagul Fibrinolysis. 2000;11(1):61-69.

126. Langeggen $\mathrm{H}$, Berge KE, Macor $\mathrm{P}$, et al. Detection of mRNA for the terminal complement components $\mathrm{C} 5$, C6, C8 and C9 in human umbilical vein endothelial cells in vitro. APMIS. 2001;109(1):73-78.

127. Langeggen H, Pausa M, Johnson E, Casarsa C, Tedesco F. The endothelium is an extrahepatic site of synthesis of the seventh component of the complement system. Clin Exp Immunol. 2000;121(1):69-76.

128. Dauchel H, Julen N, Lemercier C, et al. Expression of complement alternative pathway proteins by endothelial cells. Differential regulation by interleukin 1 and glucocorticoids. Eur J Immunol. 1990;20(8):16691675.

129. Warren HB, Pantazis P, Davies PF. The third component of complement is transcribed and secreted by cultured human endothelial cells. Am J Pathol. 1987;129(1):9-13.

130. Fischetti F, Tedesco F. Cross-talk between the complement system and endothelial cells in physiologic conditions and in vascular diseases. Autoimmunity. 2006;39(5):417-428.

131. Risitano AM, Mastellos DC, Huber-Lang M, et al. Complement as a target in COVID-19?. Nat Rev Immunol. 2020;20(6):343-344. 